\title{
LA SALVACIÓN DEL ALMA EN OSUNA DURANTE LOS SIGLOS XVIII Y XIX
}

\author{
Carlos de la Puerta Lomelino \\ Ingeniero Técnico Agrícola \\ Alumno de ISCR "San Isidoro y San Leandro"
}

\section{RESUMEN / ABSTRACT}

Este trabajo analiza unos treinta documentos testamentarios de la familia de la Puerta de Osuna (Sevilla), que nos revelan que la salvación del alma era una de las grandes preocupaciones humanas en los siglos pasados. Además de la mentalidad de la época ante la llegada del momento trascendental de la muerte, se obtienen multitud de datos sobre las costumbres funerarias, el coste de los entierros y misas, las obras sociales y de caridad a la que los difuntos destinaban parte de sus bienes, así como una gran cantidad de referencias de la vida religiosa de la Villa Ducal, de sus conventos y monasterios. Más importantes aún si cabe son las conclusiones que nos aportan los justificantes de los recibís firmados por los ejecutores de las diversas obras funerarias ante los albaceas testamentarios designados para tal efecto, ya que, debido al temor que siempre se ha tenido ante la muerte, las ocurrencias y curiosidades que se desvelan en dicho momento tan circunstancial nos pueden llegar a sorprender.

This paper analyses about thirty last will documents from family PuertafromOsuna (Seville) in which it is clear that the soul salvation was a very important issue in last centuries. Moreover these years' conceptions about the transcendental moment of death, a lot of data is observed about burial customs, costs of tombs and masses, social and charity works where death people send their money, and also many references about religious life of this small city, its convents and monasteries. It is also important to see the conclusions from the papers justifying payments (receipts) of burial buildings works and the figure of the person in charge 
of the last will, because the fear of death reveals many curiosities and issues described in such transcendental moment. Issues that can be surprising for any of us.

\section{INTRODUCCION}

Una de las grandes preocupaciones de la sociedad desde la Edad Media hasta principios del siglo XX era la salvación del alma, y ello se observa con claridad en la documentación testamentaria. Dichos escritos nos aportan además de las mentalidades de los testadores de la época, la posibilidad de descifrar la asistencia social, el porqué de las obras pías de caridad así como la actitud ante la muerte, ya que para el hombre del pasado no solo con las demandas de misas una vez llegado el momento trascendental del destino póstumo del alma, se encontraban a salvo.

En el archivo de la familia de la Puerta de Osuna (Sevilla) ${ }^{1}$ se encuentran una treintena de documentos entre testamentos, escrituras de partición y codicilos fechados entre los años 1702 y 1906, todos ellos de gran valor por los datos que nos aportan sobre las costumbres del momento, las formas de realizar los entierros, el coste de los mismos, las Iglesias y Conventos existentes en Osuna, el número de monjas de clausura en cada uno de ellos, las misas a aplicar a los difuntos, las obras pías que como última voluntad del testador debian ejecutar los albaceas testamentarios, las personas y cargos que ocupaban los recaudadores de los donativos, etc. En la mayoría de ellos figura adjunto incluso la firma del justificante de haber recibido la limosna ó el precio estipulado dando fe de haberse ejecutado dicha voluntad.

En este trabajo se pretende analizar varios aspectos, entre ellos:

- Tipos de documentos con albaceas y escribanos ó notarios.

- Los entierros propiamente dichos.

1 También se puede consultar en el Archivo Histórico Municipal de Osuna (Sevi1la) donde además se encuentran los siguientes fondos documentales: los propios del Ayuntamiento de Osuna (ss. XVI-XX); Archivo de la Antigua Universidad de Osuna (ss. XVI-XLX); Sociedad Económica de Amigos del País de Osuna (ss. XVIII-XX); documentos procedentes del Archivo de Rodriguez Marín (ss. XV-XIX) y Archivo de Protocolo y Actas Notariales de Osuna (ss. XVI-XX) 
- Las obras pías forzosas:

o De la Hermandad de la Santa Caridad.

o De la Archicofradía del Santísimo Sacramento.

o De la custodia de los Santos Lugares.

o Otras obras pias.

- Las misas aplicadas a los difuntos.

Dejaremos de lado el análisis de la partición de los bienes materiales propiamente dichos que posee el testador y la distribución de los mismos entre los familiares y allegados que tuviera lugar para centrarnos tan solo en los aspectos espirituales para la salvación del alma y observando el cambio de costumbres que existian dependiendo de las épocas de los mismos.

\section{LA OSUNA DE LOS SIGLOS XVIII Y XIX}

Pedro Girón, maestre de la Orden de Calatrava desde 1464, obtuvo del rey Enrique IV licencia para fundar un mayorazgo a favor de su hijo incluyendo territorios que comprendian Archidona, Olvera, Osuna y Morón de la Frontera, y en 1562 Felipe II eleva la condición del título a ducado. Estos datos son los que han configurado el devenir de la historia de Osuna desde el Medievo hasta nuestros dias.

Basada en una economía casi exclusivamente agrícola, las distintas desamortizaciones acaecidas desde las tímidas medidas adoptadas durante el reinado de Carlos III en 1766, la de Godoy en 1798 para finalizar con las de Mendizábal en 1837 tejieron una nueva Osuna, pasando las tierras de manos de la Iglesia, los grandes latifundios y los baldios comunales a una nueva burguesia que pronto se haría con la nobleza de la villa ducal, pero aunque para muchos supuso tan solo un cambio de dueños en las propiedades, se desarrolló una agricultura más selecta poniendo en cultivo zonas anteriormente improductivas que demandaba un mayor número de mano de obra.

Todo ello se ha reflejado como es lógico en la población, siendo de partida la que se encontró el primer Conde en 1564 tan solo de 519 vecinos, aunque Jerónimo Munzer treinta años después a su 
paso por Osuna, dice haber visto "más de trescientos sarracenos sujetos con grillos." 2 Pero el número de habitantes continuó creciendo en las próximas décadas, y así queda corroborado por el arrendamiento de 1528, donde se afirmaba que Osuna contaba con "1294 vecinos, a los que les correspondia pagar 122.110 maravedis, aunque por la calidad y cantidad de vecinos deberian de pagar 170.000 maravedis." 3 Este desarrollo demográfico es debido a la existencia en el primer tercio del siglo XVI de tres repartos de montes y rozas, como iniciativa repobladora ${ }^{4}$. Y aunque durante los siglos XVIII y XIX la población fue creciendo paulatinamente, lo hacía en menor cuantía que en los dos anteriores, así en 1751 según el catastro del Marqués de Ensenada Osuna llegó a tener 15.123 habitantes y según la población del interrogatorio de 1803 la cifra ascendia hasta los $23.144^{5}$, mientras que en 1900 alcanzaba los $18.072 .{ }^{6}$

Pero aparte de la agricultura existian dos grandes referentes en la villa: el Colegio-Universidad de la Purísima Concepción, fundado en 1548 por Don Juan Téllez-Girón, denominado el Santo, IV Conde de Ureña y padre del primer Duque de Osuna permaneciendo como centro docente hasta 1824, alcanzando cierta notoriedad por ser mencionada en el Quijote ${ }^{7}$, y la construcción por las mismas fechas

2 Jerónimo MUNZER. "Viaje por España y Portugal”. Ed. Polifemo. Madrid, 1991, pág. 151. Este método opresivo se usaba para evitar que se fugasen a Granada para obtener los beneficios que ofrecian a los nuevos pobladores.

3 A.G.S. Contaduria Generales. Leg. 768 , fol. 408 vto.

4 Cf. Francisco LEDESMA GAMEZ. "Las murallas de Osuna". Fundación El Monte. Sevilla. 2003.

5 Acta capitular de fecha 20 de julio de 1752 , en la petición que D. Alonso Romero hace al Rey para que lo exima de cargos públicos dice:"... componiéndose esta villa de ocho mill vezinos y entre ellos muchas personas aviles para el uso y exercisio de semexanttes empleos...".

6 Fuente "Instituto Nacional de Estadística". En este dato de 1900 no se incluyen los habitantes de las poblaciones que componen su jurisdicción, mientras que en las anteriores cifras si están incluidos.

7 Luis E. RODRIGUEZ-SAN PEDRO BEZARES. "Atmosfera Universitaria en Cervantes”. Universidad de Salamanca. 2006. Página 19. La Universidad de Osuna es citada en el libro inmortal de Cervantes, "Don Quijote de la Mancha" varias veces con ironía, asi en Quijote II, capítulo I, se contraponen las ridículas graduaciones de la Universidad de Osuna con las de Salamanca, y de igual forma también en Quijote II, capitulo XLVII. 
de la Iglesia Colegial de la Asunción que en 1534 con la obra del templo ya iniciada obtuvo una bula del papa Paulo III permitiendo la implantación de una colegiata, dotada con un cabildo compuesto por un capellán mayor y ocho capellanes de coro.

A partir de entonces se instalaron en Osuna numerosas órdenes y cenobios que atrajeron a la población un número muy importante de clérigos. Según las inspecciones pastorales de 1728, existían entonces 11 conventos masculinos y 6 femeninos, incluyéndose en ellos un colegio de jesuitas y una agrupación de beatas. Entre los primeros se encontraban los dominicos, los franciscanos observantes, los mercedarios descalzos, terceros de San Francisco, carmelitas calzados, agustinos descalzos, mínimos de San Francisco de Paula, jesuitas y religiosos de San Juan de Dios, a los que se añadieron más tarde los religiosos del Santo Espíritu, y por último una congregación de recoletos de San Francisco que por su advocación dieron nombre al paraje donde se asentaron: el Calvario. También realizaba una gran labor el "Seminario del Corpus Christi" con cabida para 12 estudiantes que se comprometían a acompañar a los viáticos en sus salidas públicas. Entre los femeninos se encontraban bajo la jurisdicción de sus hermanos las dominicas de Santa Catalina, las franciscanas de Santa Clara y mercedarias descalzas, y dependientes de la jurisdicción del Arzobispado las franciscanas de la Concepción y las carmelitas calzadas, existía además un beaterio conocido como de la "Magdalena" que recogía a mujeres escandalosas antes de proceder a ser expulsadas por la justicia. ${ }^{8}$

Además de los centros que dichas ordenes mantenían abiertos al culto, existían en la población varias ermitas donde se atendía espiritualmente a la población indigente como eran Santa Ana, San Antonio Abad, San Arcadio, la Vía Sacra y Santo Cristo de la Puerta Ronda. Hay que añadir por último la existencia de once oratorios y capillas privadas. Es necesario reseñar que la asistencia

8 Cf. M. L. CANDAU CHACÓN. "Osuna y su clero en el siglo XVIII". Del libro "Osuna entre los tiempos medievales y modernos (siglos XIII - XVIII). Juan José Iglesias Rodriguez y Manuel García Fernandez. Universidad de Sevilla. 1995. Páginas 389-412. 
hospitalaria para la recogida de pobres transeúntes se realizaba en San Sebastián y la Providencia.

En 1725 consta que había en Osuna 118 clérigos y en 1755 el número ascendia hasta 164, ello era debido a que pertenecer al estamento eclesiástico en dicha Villa poseía grandes ventajas no solo de indole fiscal, sino que también contaban con cuantiosas prerrogativas y beneficios propias de su jurisdicción señorial y las manifiestas de su Cabildo e Iglesia Colegial. ${ }^{9}$

\section{TIPOS DE DOCUMENTOS}

Entre los tipos de documentos analizados podemos destacar los testamentos, los codicilos y las escrituras de partición. Los primeros según el Diccionario de la Real Academia de la Lengua Española son un "negocio jurídico consistente en una declaración de voluntad por la que una persona ordena el destino de sus intereses para después de su fallecimiento", pero aunque en un principio se utilizan para regular el destino de los bienes materiales del testador para que no queden en una situación de abandono y desamparo, tradicionalmente se han incluido en los mismos otras disposiciones de carácter estrictamente personal carentes de todo valor jurídico como la profesión de una determinada religión. ${ }^{10}$

Todos ellos se realizan bien ante un "escribano" que según el Diccionario citado con anterioridad se refiere a "el que por oficio público estaba autorizado para dar fe de las escrituras y demás actos que pasaban ante él' y a partir de la ley orgánica de 28 de mayo de 1862 donde se regula el estatuto del notario quedando unificado para toda España, por estos mismos que según el Diccionario referido es el "funcionario autorizado por la ley para dar fe pública de los contratos, testamentos y otros actos extrajudiciales". La diferencia pues entre unos y otros radica en que aquellos eran designados por las autoridades públicas a quienes quedaban sujetos mientras

Ibid.

10 REAL ACADEMIA ESPAÑOLA. "Nueva Enciclopedia Larousse”: Tomo 19. Planeta. Barcelona. 1980. Término testamento, página 9632. 
que los notarios tenian estipulada una autonomía total respecto al poder existente aunque estuviesen vinculados como funcionarios al Ministerio de Justicia. ${ }^{11}$

La profesión de nuestra religión se observa con claridad en los testamentos analizados de dicha época, siendo la mayoría de ellos una autentica confesión de fe y desde las primeras palabras escritas que aparecen así lo atestiguan, y para ello sirva como muestra:

"En el nombre de Dios Nuestro Señor todo poderoso, amen. Sepan como yo D. Fco. de la Puerta, natural de............., hallándome en completa salud y en mi acuerdo cumplidor y buena memoria, creyendo como firme y verdaderamente creo y confieso el alto e inefable misterio de la Santisima Trinidad, que es Padre, Hijo y Espiritu Santo, tres personas que aunque realmente distintas tienen una misma esencia $y$ atributos y son un solo Dios verdadero y en todos los demás misterios y sacramentos que tiene, cree, predica y enseña Nuestra Santa Madre Iglesia Católica, Apostólica y Romana, en cuya verdadera fe y creencia he vivido y protesto vivir y morir como fiel católico cristiano, tomando por mi especial protectora y abogada a la que por esencia lo es de pecadores María Santisima, Madre de Dios, Reyna de los Ángeles y Señora Nuestra y por medianeros al Santo Ángel de mi Guarda, los de mi nombre y devoción y demás de la Corte Celestial, para que imploren de Nuestro Señor y Redentor Jesucristo el perdón que espero de mis culpas y lleve mi alma a descansar a su beatifica presencia: temiéndome de la muerte que es tan precisa, como incierta su hora para que cuando llegue me encuentre prevenido en todas las cosas concernientes al descargo de mi conciencia, otorgo: que hago y ordeno mi testamento en la forma siguiente: Ofrezco y encomiendo mi alma a Dios Nuestro Señor, que la crió de la nada y redimió con el precio infinito de su preciosa sangre, vida, pasión y muerte, y mando el cuerpo a la tierra de que fue formado....". ${ }^{12}$

En algunas ocasiones los testamentos son redactados imaginamos que en el mismo lecho de muerte, como ocurre en “... estando enfermo del Cuerpo y Sano de la Boluntad, y en mi Juicio, memoria y entendimiento natural el que Dios nuestro Señor ha Sido

11 REAL ACADEMIA ESPAÑOLA. "Nueva Enciclopedia Larousse”. Tomos 7 y 14, Planeta. Barcelona 1980. Términos escribano (pág. 3457) y notario (pág. 7063).

12 Testamento de Francisco de la Puerta Zamora. 5-8-1842. Escribano Antonio Manuel de la Barrera. 
Servido darme,..." expresando más adelante en el momento de la firma que "En testimonio de lo qual otorgué la presente ante el Escrivano público, y testigos en cuya respuesta no la firmo por la gravedad de mi enfermedad lo hace a mi ruego un testigo que lo fueron...". ${ }^{13}$

Otros tipos de documentos analizados son los codicilos, que son una disposición breve de última voluntad sin institución ó cambio de heredero, para reformar ó adicionar parcialmente los testamentos (como un anexo al testamento que lo completa). ${ }^{14} \mathrm{Y}$ por último se encuentran los cuadernos de partición redactados por los albaceas y una vez realizadas las disposiciones tanto materiales, formales y espirituales, y que como es lógico han de firmar los herederos y participantes en el mismo y que también pueden ser escriturados por escribanos ó notarios.

\section{LA LABOR DE LOS ALBACEAS}

Una figura muy importante en el derecho sucesorio y de donaciones es la del albacea, que como define nuestro diccionario es la "persona nombrada por el testador para hacer cumplir y ejecutar su última voluntad"15 y en este caso particular, el del albacea solidario para realizar dicha función en la parte exclusivamente solidaria. Por regla general se designan personas de total confianza para el testador recayendo en la mayoría de los casos en familiares directos del mismo. También es de resaltar que cuando la persona designada ostenta algún tipo de cargo se reseña en el documento. En la burguesía y la nobleza de la época era propio tener algún familiar que formara parte de la curia eclesiástica, y en tal caso siempre era el designado para ocupar dicho encargo.

13 Testamento de Francisco de la Puerta Lebrón, 17-4-1817. Escribano Antonio José Rodriguez. El entierro tuvo lugar el 22 de abril del mismo año.

14 Cf. M. AlBADALEJO y otros. Tomo XXXVII - Vol. 1 ${ }^{\circ}$. Libro II. "De las donaciones y sucesiones". Leyes 148 a 252 de la Compilación o Fuero Nuevo de Navarra. Comentarios al Código Civil y Compilaciones Forales. Edersa, (1998).

15 REAL ACADEMIA ESPAÑOLA. "Nueva Enciclopedia Larousse". Tomos 1. Planeta. Barcelona. 1980. Término albacea, página 230. 
Y como queda reflejado en la mayoría de los documentos analizados, "y para cumplir y pagar este mi testamento nombro por mis Alvaceas executores dél a D......... a los quales y acada unodoy poder cumplido para que por mi fallecimiento entren en mis vienes, tomen dellos los que pacten, y los vendan en Almoneda pública ó fuera de ella y a un valor lo cumplan y paguen con la brevedad posible, sobre que les encargo las consiensias."16

En muchos de los testamentos estudiados, se observa con claridad la celeridad con la que los albaceas ejecutaban el encargo del difunto, y ello es de suponer que era debido el poder disponer de dinero en efectivo para sufragar los cuantiosos gastos que suponian todas las mandas del testador, sin tener que acudir a la almoneda pública. Así por ejemplo en un entierro celebrado el 22 de abril de 1817, antes de final de mes se han firmado todos los justificantes de haber recibido el importe estipulado que ascendió a la cantidad de $6.482,18$ reales de vellón, quedando constancia en dicho testamento que "el fiscal lo ha visto y no se le ofrece reparo, ossuna y mayo cinco de mil ochocientos diez y siete. D. José Rodriguez Quesada"17 siendo rubricado además del escribano, por el fiscal y por el Alcalde Mayor. La venta en almoneda pública que como define nuestro diccionario es la "venta pública de bienes muebles con licitación y puja"18 conllevaba una mala venta por ser realizada con premura y por consiguiente una pérdida de dinero.

En algunos casos eran los encargados de dirimir el número de misas a aplicar por las intenciones del difunto como por ejemplo "Mando se digan por dicha mi Alma..... las misas rezadas por una vez y se pague por su limosna lo que uno y otro sea voluntad de mi Albasea, queedenombrar."19 Pero en muchos otros se dejaba a su elección las Iglesias ó clérigos que oficiarían dichas misas como queda reflejado por el notario Manuel Fernandez y García en "Manda que por su alma é intención se apliquen veinte misas

16 Testamento de Francisco de la Puerta Lebrón, 17-4-1817. Escribano Antonio José Rodriguez.

17 Ibíd.

18 REAL ACADEMIA ESPAÑOLA. "Nueva Enciclopedia Larousse”. Tomos 1. Planeta. Barcelona. 1980. Término almoneda, página 340.

19 Testamento de Pedro Pele de Verges, 27-12-1768. Escribano Juan Lopez Salcedo. 
rezadas, cuarta parte por colecturia de esta Parroquia, y las restantes por los sacerdotes que digan sus albaceas. "20

En el anexo número 1 se encuentran además del nombre del testador ó testadores (los matrimonios muchas veces lo realizaban en conjunto), el tipo de documento y la fecha de escrituración del mismo, los albaceas de la parte solidaria así como algunas observaciones a tener en cuenta.

\section{ENTIERROS}

En los testamentos a continuación de la fe que profesa el testador a la que nos hemos referido con anterioridad, el mismo desarrolla las "mandas" que desea sean cumplidas una vez fallecido, y la primera de ella es lógicamente la organización de su propio entierro. Así se puede leer:

"Ofrezco y encomiendo mi alma a Dios Nuestro Señor, que lo crió de la nada y redimió con el precio infinito de su sagrada vida, pasión y muerte, y mando el cuerpo a la tierra, del que fue formado, el cual vestido con la ropa de mi uso sea sepultado en el enterramiento público de esta villa, con caja propia dejando la forma del funeral y disposición de mis albaceas. Mando acompañen a mi cadáver hasta el enterramiento público veinteicuatros pobres con velas encendidas dándoseles a estos dos R. V. de limosna". ${ }^{21}$

Analizando los textos se observan los cambios de costumbres de las épocas, así antes de 1847 en Osuna eran habituales los enterramientos en los conventos, siendo los difuntos amortajados con el hábito del mismo, y a partir de la creación de un cementerio público en dicho año lo hacian con la ropa de su uso dejándolo reflejado en el testamento. Así por ejemplo el padre del anterior difunto desea que " mi cuerpo sea sepultado en la Iglesia del Convento del Señor San Agustín, y le sea vestido por mortaja el avito de que

20 Testamento de Aniceto de la Puerta y Zayas. 27-8-1898. Notario Manuel Fernández y Garcia.

21 Testamento de Antonio Maria de la Puerta Zamora, 31-3-1860. Escribano Manuel de la Barrera. 
vian los religiosos del mismo, puesto en caxa propia y forrada...".22. Prueba de la necesidad que existía en Osuna a mediados del siglo XIX de un cementerio público quedó reflejado por el escribano Juan Bautista Pardillo en el testamento fechado en 1834 en el que la testadora "Mando que mi cadáver sea sepultado en el paraje que tenga dispuesto el Gobierno...". 23

Pero lo que nos da muestra de todas las personas que intervienen en un entierro son algunos recibís perfectamente detallados, donde además del número de clérigos concelebrantes determinados por el difunto en el testamento existiendo entierros de 6, de 8, de 12, de 20, y hasta de 32 (en 1819 cobraban los clérigos por asistir 5 reales de vellón), han de intervenir el sacristán, los acólitos, el campanero, los portadores tanto de la caja como de la capa fluvial y de la cera, el sepulturero, los componentes de la capilla musical, etc. Así consta en el siguiente documento fechado en 1770:

"Como Collector de Obenciones de la Insigne Iglesia Collegial de esta villa, recibi de $D^{a}$. Florentina Hidalgo Alvasea y heredera de $D^{\circ}$. Pedro Pelé su marido ciento noventa y ocho reales de vellón y veinte y cuatro maravedies de los derechos del entierro de doce con música que se le hizo al susodicho en el Convento del Carmen el dia veinte y tres del corriente. Y son del Beneficio, Ofrendas, Vigilia, Missa y Ministros, Clero, Cera, Fábrica, Cruz, Capa pluvial, Sachristan mayor, Acólitos, Doble de campanas y entierro. $Y$ lo firme en Ossuna en Febrero veinte $y$ cinco de mil setecientos y setenta años. Asi mismo recibi treinta y tres reales de vellón de la Capilla de Musica. $D^{\circ}$. Joseph Isidoro Carrasco". ${ }^{24}$

En la mayoría de los documentos figura también el recibí correspondiente del coste del hábito con el que el difunto fue sepultado, "Recibi de los Sres. Albaceas testamentarios del Sr. $D^{\circ}$ Joseph Hidalgo Difunto Quarenta y quatro r. V. de limosna del Abito con que dicho Sr. fue amortajado y por ser verdad lo firmé en este Convento de N. P. Sto. Digo. de Ossuna, 18 de Nbre. de 1769.

22 Testamento de Francisco de la Puerta Lebrón, 17-4-1817. Escribano Antonio José Rodriguez.

23 Testamento de Paula Rodriguez de Gracia. 3-10-1834. Escribano Juan Bautista Pardillo.

24 Testamento de Pedro Pele de Verges, 27-12-1768. Escribano Juan Lopez Salcedo. 
Fray Fco. Rosales", ${ }^{25}$ e igual acontece en cuanto a la caja empleada para dicho menester debiendo ser "...puesto en caxa propia forrada y costeada a mis expensas y conducido por quatro pobres dando a cada uno la limosna de diez reales de vellón y encargándoles me encomienden a Dios...", y es cierto que fue costeada por el difunto como prueba el justificante que establece "Como Maestro Carpintero que soy de esta Villa he recibido de los Albaseas testamentarios de $D^{o}$. Fco. de la Puerta, la cantidad de ciento sesenta y dos $R$. Vellon de la caja forrada que he hecho $p^{a}$ este Señor, y $p^{a}$ que conste doy el presente que firmo en Osuna a 28 de Abril de 1817. Juan Manuel Morales. "26

Además del habito con el que el difunto viajará a la eternidad, era importante que la caja mortuoria no fuese usada y en la elección del nicho se observa el sometimiento con el que se entregaban una vez más a la Iglesia local, así se refleja en "que mi cuerpo sea amortajado con avito del Señor Santo Domingo y metido en caja nueva me entierren en la Yglesia que su religión tiene en esta villa en la sepultura que el padre prior del fuese servido señalarme...". ${ }^{27}$

En 1837 el acompañar al funeral con el doblar de las campanas de cada uno de los conventos existentes en la Villa Ducal costaba 20 reales de vellón, y si en vez de 2 campanas el cenobio poseía 4 como ocurría con el Convento de la Victoria, el precio se duplicaba, ello se deduce de los justificantes de cobro rubricados en octubre de dicho año que acompañan al testamento de Pedro Rodriguez y Gracia. De los mismos recibís se observa con claridad el número de monjas de clausuras existentes en cada monasterio de Osuna, ascendiendo la totalidad a 89 ya que además recibieron una limosna por cada componente del convento, así como el nombre de las superioras de cada uno de ellos. ${ }^{28}$

25 Testamento de Joseph Hidalgo Romero, 7-11-1769. Escribano Juan Bello.

26 Testamento de Francisco de la Puerta Lebrón, 17-4-1817. Escribano Antonio José Rodriguez.

27 Testamento de Pablo Diez Hidalgo. 17-11-1702. Escribano Antonio Mancera de Roa.

28 Testamento de Pedro Rodriguez y Gracia, 26-6-1815. Escribano Juan Bautista Pardillo. 
Es evidente que siempre han existido clases más privilegiadas, y ello se demuestra no solo en el número de clérigos asistentes al entierro, sino también por otros detalles que no pasan desapercibidos como por ejemplo se demuestra en el justificante que atestigua "He recibido de los Sres. Albaceas testamentarios de la Sra. Doña Francisca Tamayo Marquesa de Casa Tamayo, la cantidad de ciento veinte reales, derechos por haberle adornado la sala mortuoria de damascos, y para que conste doy este en Osuna a veinte y nueve de Julio de mil ochocientos veinte y nueve. Manuel Martín."29

A partir del año 1860, con la inauguración del Asilo de Ancianos de Osuna por parte de su fundadora la Condesa de Puerto Hermoso y la llegada posterior en 1881 para hacerse cargo del mismo de las Hermanitas de los Pobres, mujeres que continuaban el camino señalado por Juana Jugan ${ }^{30}$, se observa en los testamentos que desde dicha efemérides existe el deseo de ser acompañados por los residentes, asi se puede leer "Manda que cuando ocurra su fallecimiento se le haga entierro de segunda clase al que concurran todos los pobres del Asilo y los particulares que quieran sus albaceas abonándoseles a cada uno la cantidad de cincuenta céntimos de peseta." $" 31$

Existen algunas curiosidades debidas quizás a supersticiones de la época ó del propio testador, detalle que se puede observar por ejemplo en "Si se construyese panteón familiar y acordasen la traslación de su cadáver manda y ordena no se le coloque sobre la tierra sino en un nicho alto"32, ó la escasa solidaridad al reclamar el derecho de exclusividad en "Que su cadáver sea colocado en nicho propio en el Cementerio Católico de esta villa en cuyo nicho en ningún tiempo podrá colocarse ningún otro cadáver". ${ }^{33}$

29 Testamento de Francisca de Paula Tamayo y Carvajal, marquesa de Casa Tamayo, 25-5-1875. Escribano Leonardo Recio Reyes.

30 Cf. S. AGUILAR, "Cien años de intensa labor", ABC de 25 de Octubre de 1981.

31 Testamento de Aniceto de la Puerta y Zayas, 27-8-1898. Notario Manuel Fernández y García.

32 Testamento de Victoria de la Puerta y Zayas, 10-10-1901. Notario Manuel Fernández García.

33 Ibid. 
En el anexo $\mathrm{n}^{\circ} 2$ quedan reflejados muchos de los aspectos $\mathrm{y}$ curiosidades reseñadas en este epígrafe así como otras cuestiones dignas de tener en cuenta. En dicho anexo se incluye la fecha de redacción del documento, el testador, el templo donde se ha realizado el entierro y otros gastos del mismo, la fecha del recibí y el firmante del mismo, el coste y un apartado de observaciones.

\section{LAS OBRAS PÍAS FORZOSAS}

En los siglos XVII y XVIII existía una gran preocupación por la salvación del alma, continuando también hasta finales del XIX y principios del XX, y ello evidentemente se manifiesta a la hora de la redacción de los documentos a través de las mandas pías testamentarias que si bien no podrá disfrutarlas en vida el legatario, si le servirán como consuelo cuando llegue la hora de su muerte ${ }^{34}$. Con ellas el testador pretendía lograr beneficios en favor de su alma, donando cierta cantidad monetaria en beneficio de las personas más necesitadas (pobres, huérfanos, esclavos, cautivos, etc.) ó a favor de instituciones religiosas (hermandades principalmente). Pero aunque casi la totalidad de los testamentos incluyen, no solo una sino en la mayoría de las ocasiones varias clausulas de este tipo, "su repercusión económica en el montante total del testamento no era, en general muy importante, ya que la cantidad de dinero que se destinaba a cada una ascendia a unos pocos reales en la mayoría de los casos y es que, su valor no podia exceder de la cuota de libre disposición." ${ }^{35}$

Pero estas obras pías son sin lugar a dudas de origen medieval, provenientes con seguridad de una evolución de la cuota de libre disposición que existía en el derecho visigodo y que continuó en los primeros tiempos de la reconquista, de esta forma la quinta libre visigoda a través de la influencia eclesiástica empezó a destinarse

34 María del Pilar Estevez Santamaria, "Practicas Testamentarias en el Madrid del siglo XVI: Norma y Realidad" Conferencia impartida en las IX Jornadas Científicas sobre Documentación "La muerte y sus testimonios escritos" celebradas en la Facultad de Geografia e Historia de la Universidad Complutense de Madrid durante los días 3, 10 y 17 de marzo de 2010.

35 Ibid. 
a la Iglesia en beneficio del alma, para convertirse en la Edad Media en las cuotas pro animas que eran consideradas por los legisladores como obligatorias para poder sufragar con ellas obras de caridad. Con el paso del tiempo dio lugar en la época moderna, en los siglos XVII y XVIII, a las mandas pías forzosas cuyo nombre nos induce a una gran confusión, ya que "el carácter de obligatorias ó forzosas que las caracteriza no debe tomarse al pie de la letra, sino que consistiría en una recomendación ó recordatorio que le hacía al testador el notario que tomaba nota de su última voluntad, sin que existiese más compromiso que el moral a la hora de aceptar ó rechazar el sugerimiento" 36 , no existiendo ninguna legislación al respecto sobre su obligatoriedad.

Es curiosa la redacción de dichas mandas, dejando siempre bien claro que eran por una sola vez y que no podian pretender otros derechos sobre los bienes del testador:

"Yo sedo de limosna por una vez, a las obras Pias y mandas forzosas de este Arzobispado dos Reales de Vellón; otros dos en igual conformidad a la cofradia de la Santa Charidad, para sus santos fines con que las segrego del derecho que puedan tener a mis vienes, $y$ en igual forma de por una vez, se den otros dos reales de limosna a la Archicofradia del Santísimo Sacramento de esta Villa." ${ }^{\text {37 }}$

Por lo general existian tres obras pias en las que la mayoria de los testadores y documentos examinados ofrecian sus donativos, siendo estas la Cofradía de la Santa Caridad, la Archicofradía del Santísimo Sacramento de la Insigne Iglesia Colegial y los donativos destinados para la custodia de los Santos Lugares de Jerusalén. De esta última no se hace mención hasta el siglo XIX. En los anexos 4, 6 y 7 respectivamente se señalan además del testador, la limosna ó donativo, la fecha en la que se ha recibido por el destinatario la cantidad estipulada así como el nombre y cargo de la persona que efectúa el cobro del mismo. Por regla general las cantidades destinadas a dichas obras eran 2 reales de vellón, siendo las

36 Modesto V. Barrera Aymerich. Religión y asistencia social en el antiguo régimen. Las mandas pías de los testadores de Castelló y Borriana durante los siglos XVII y XVIII. Revista de Historia Moderna. Número 16. 1990. Página 119.

37 Testamento de Pedro Pele de Verges. 27-12-1768. Escribano Juan Lopez Salcedo. 
variaciones mínimas (entre 0,5 y 4), a partir del 19 de octubre de 1868 con la entrada en vigor de la nueva moneda las cantidades oscilan entre 0,5 y 2 pesetas. ${ }^{38}$

En el anexo número 8 podemos analizar otras obras pías a las que se han donado limosnas, destacando la redención de cautivos cristianos, los niños expósitos y los huérfanos y viudas de la guerra de la independencia española (1808-1814) ante la invasión francesa.

Con todas estas mandas se observa con claridad que hasta principios del siglo pasado existió una gran influencia medieval a la hora de realizar dichas labores sociales, resaltando sobremanera el temor a que tanto los Santos Lugares de Jerusalén como los cautivos cristianos caigan en manos de los infieles que profesan la religión de Mahoma, por ello se destinan donativos para la custodia del Santo Sepulcro que recaudan los padres franciscanos, y para la redención de los prisioneros en tierras del Islam que recibian los padres mercedarios, ya que existía la creencia de que los mismos por estar en manos del enemigo tenían el alma perdida si eran desposeídos de nuestra fe.

Otra manda forzosa a destacar era la destinada a los niños expósitos que según el Diccionario de la Real Academia de la Lengua Española "dicese del que, recién nacido, ha sido abandonado en un parque ó dejado en la inclusa." ${ }^{39}$. Solía tratarse de niños procedentes de partos fuera de matrimonio, o huérfanos de padre en situación de pobreza extrema. El nombre procede del latín ex-posĩtus, puesto afuera y solían entregarse a instituciones de beneficencia denominadas casas u hospitales de expósitos.

Considero también importante reseñar que en la mayoría de los documentos analizados figura al final de los mismos el correspondiente recibí firmado por el miembro de la hermandad ó congregación que ha recaudado el donativo señalado por el

38 Cf. http://es.wikipedia.org/wiki/Peseta [consulta 15-11-2014].

39 REAL ACADEMIA ESPAÑOLA. "Nueva Enciclopedia Larousse". Tomo 8. Planeta. Barcelona. 1980. Término expósito, página 3774. 
testador, así por ejemplo en el testamento de Pablo Diez Hidalgo se puede leer en letra escrita y firmada por Juan Pleittes que "Como Diputado que soy de la Archicofradia del SS. Sacramento de esta villa, recivi de los albaceas de $D^{\circ}$. Pablo Diez Hidalgo los dos $r . v$. que pone en una de sus clausulas de su testamento mando a la archicofradia $y p^{a}$ que conste lo firme Ossuna y febrero veinte $y$ tres de mil setecientos sesenta y ocho años." 40

También he realizado un estudio de los distintos nombres con los que se designa a la Hermandad Sacramental, tanto por parte del testador (se supone que es el escribano ó notario quien lo decide) y por parte del miembro de la junta de gobierno que recibe el donativo, quedando reflejado en el anexo $n^{\circ} 5$. En general es más común el empleo del término Cofradía que el de Hermandad. Como curiosidad Laureano Vicente Gomez en 1750 firma "Como Diputado de la Archicofradía de la SSma. Resurreeccion de Xpto. Sacramentado, cita en la Capilla del Sagrado Comulgatorio de la Yncigne Yglesia Colegial de esta villa he recibido dos $r$. de Vellon de los albaceas..." ${ }^{41}$

\section{LAS MISAS}

El hombre, como señala Morín ${ }^{42}$ es el único ser que tiene, no solo miedo, sino horror a la muerte, y ello lo ha sabido capitalizar la Iglesia organizando y explotando la entrada en la inmortalidad buscando el beneficio espiritual y personal del difunto ${ }^{43}$. Por ello y para redimir el alma, los testadores encargaban a los albaceas solidarios el mayor número de misas posibles que estimaban necesarias y que su economía le permitía pagar, sufragios que solicita tanto para su propia salvación como de sus familiares y que se justificaban "por cuanto, para el cristiano, la vida en la tierra es sólo un peregrinar en busca del más allá de su auténtica vida en compañia de Dios por toda la eternidad: esa vida eterna y perpetua

\footnotetext{
Testamento de Isabel Montero, 6-2-1768, Escribano Juan Joshep Carreras.

1 Testamento de Francisca Hidalgo. 7-2-1750. Escribano Antonio Fco. Romero.

2 Cf. E. MORIN, "El hombre y la muerte". Barcelona, Kairós, 1974, página 78.

3 Cf. A. RODRIGUEZ SÁNCHEZ, “Morir en Extremadura”, 1980.
} 
era la única que importaba, y a conseguirla se dirigian todos los esfuerzos." $" 4$

Como la Iglesia había difundido por toda la cristiandad la existencia del purgatorio donde se expiaban las penas de los que habian fallecido en estado de imperfección, la ayuda para salir del mismo tan solo podía llegar desde la Tierra a través de las misas que encargaban sus familiares y es por ello la imposición testamentaria. $^{45}$ Esta convicción proviene desde la época carolingia y tuvo como consecuencia su traducción litúrgica en la multiplicación de las misas votivas por personas o, simplemente, como forma de sustitución de obras de expiación. La eucaristía se había convertido en la misa privada, y es por lo que cuantas más misas celebradas diariamente más posibilidades de conseguir el favor. Ella es la explicación del aumento del número de misas y por lo tanto de los monjes, laicos no ordenados en su mayoría, que pasaron a ser presbíteros celebrantes de misas, y el enriquecimiento de los centros monásticos desde el siglo IX. ${ }^{46}$

A raíz de ello la Iglesia instaura la figura del colector parroquial, que surge debido a la necesidad de fiscalizar el que efectivamente se estuviesen celebrando las misas solicitadas por los fieles en los testamentos. Dicha persona, clérigo o seglar, estaba legitimada para exigir el cumplimiento de las cargas espirituales que se habían detallado en los testamentos, así como recaudar los donativos de las eucaristías que se oficiaban para distribuirlas entre los celebrantes. Se establecía que una cuarta parte de las misas aplicadas al difunto se realizaban por colecturía, es decir, eran distribuidas para ser oficiadas por los clérigos que tenían menos ingresos, mientras que el resto estaban designadas bien en determinados conventos y/ó

44 J. MARTÍNEZ SANZ, "Una aproximación a la documentación de los archivos parroquiales de España”. Hispania ${ }^{\circ}$ 162, página 185. 1986.

45 Cf. M. CALVO CRUZ; C. CASTRO PEREZ; S. GRANADOS SUAREZ. "Análisis de una defunción en los siglos XVII y XVIII a través de las anotaciones contables que realizaba el colector parroquial". Tiempos Modernos. Revista electrónica de Historia Moderna, Volumen 5, Número 15, 2007, página 312.

46 Cf. J. L. GARCIA DE LA MATA CALVO. "Guia de estudio para la historia de la Iglesia antigua y medieval". Instituto Superior de Ciencias Religiosas San Isidoro y San Leandro de Sevilla. Octubre 2014. Página 86. 
Iglesias ó por clérigos conocidos y allegados. De la importancia del colector nos damos cuenta en que en 1738 era colector Julián de Mola y Ochoa, y en la inspección pastoral de 1739 había recibido en colecturía 18.201 misas procedentes de testamentos, abintestatos, misas votivas y adventicias. ${ }^{47}$

Son cuantiosas las conclusiones que se pueden extraer analizando el anexo $n^{\circ} 3$, la primera de ellas es la cantidad de misas solicitadas y realizadas, en algunos casos se piden hasta un millar, como por ejemplo solicita Pablo Diez Hidalgo "que se digan por mi anima é intensión mil misas resadas, la quarta parte en la colecturía de la Santa Iglesia Collegial de esta villa, quinientas en dicho convento del Señor Santo Domingo de ella y las restantes en dicho convento del Señor San Francisco, nuestra Señora del Carmen y collegio de nuestra Señora de la Victoria por sus religiosos a elección de los albaceas que ê de nombrar..." ${ }^{48}$. En la mayoría de los casos el testador solamente indica el número de misas que quiere dejando la elección del lugar a los albaceas, mientras que en otros casos se señalan los conventos donde se desean que sean aplicadas.

Se puede incluso obtener la depreciación de la moneda por el coste de las misas en las distintas épocas, y así hasta 1760 se pagaban a 2 reales de vellón cada una, en 1770 su precio había ascendido a 3, en 1810 costaban 4, en 1817 su costo era de 5 y en 1860 su precio ascendía a 6 reales de vellón. Aunque la mayoría de las misas eran rezadas, también se realizaban las cantadas de mayor precio como así consta en el justificante "... recibi de los albaceas testamentarios del s. $D^{\circ}$. Pablo Hidalgo (qe. de Dios gose) ciento y ochenta $r$. $V$. limosna de noventa missas rezadas con mas treinta y tres $r$. V. de la missa cantada...". ${ }^{49}$

47 Cif. J.SANCHEZ HERRERO. "Osuna. La villa y su gobierno ducal. La Iglesia y la religiosidad (1695-1739)". Del libro "Osuna entre los tiempos medievales y modernos (siglos XIII - XVIII). Juan José Iglesias Rodriguez y Manuel García Fernandez. Universidad de Sevilla. 1995. Página 370.

48 Testamento de Pablo Diez Hidalgo, 17-11-1702. Escribano Antonio Mancera de Roa.

49 Ibid. 
Existían también las misas llamadas de privilegio como son las de San Juan de Letrán, San Gregorio, San Vicente, San Francisco de Paula y San Gerónimo, así por ejemplo lo estipula Victoria de la Puerta y Zayas en 1901 “...Además ordena se le apliquen las misas de San Gregorio, de San Juan de Letrán y las de San Francisco de Paula". ${ }^{50}$ Es evidente que dichas misas de privilegio tenían un coste adicional, así por ejemplo las de San Vicente en 1837 costaban unos 10 reales de Vellón. Algunos difuntos habían encargado misas en determinadas capillas ó altares como por ejemplo " $Y$ Es mi voluntad, se digan por una vez, tres misas rezadas en el Altar del Señor San Geronimo, sita en su Capilla del Santo Sepulcro de Corpus Christi por sus Capellanes y por limosna de cada una se den tres reales de Vellón." 51

Las misas se solicitaban no solo por las intenciones y animas del difunto, sino también por sus familiares y allegados como demuestra "Mando se digan por dicha mi Alma e yntencion, las de dichos mis Padres, y demás personas aquienes pueda ser en alguna cosa de cargo, las misas rezadas...." ${ }^{22}$, e incluso por los clérigos como consta en "...se diga por dicha mi Alma eyntencion misa de Requien cantada, con Vigilia, Responso y demás exequias acostumbradas, y en igual conformidad se diga otra por los religiosos del expresado convento donde me mando enterrar, por que así es mi voluntad." ${ }^{\text {33 }}$

La aplicación de las misas se observa que la mayoría de las veces se realizaban de forma maratoniana, llegando incluso a oficiarse 69 en 5 días como consta por ejemplo en el justificante del testamento de Francisco de la Puerta Lebrón fechado el 26 de abril de 1817 "Sean recibido en este Colegio...... trescientos quarenta y cinco $r$. V., limosna de sesenta y nueve misas qe. sean aplicado desde veinte $y$ uno de Abril asta venteicinco del mismo por el alma e..."54 También se puede apreciar la existencia del regateo, muy común en las

\footnotetext{
50 Testamento de Victoria de la Puerta y Zayas, 10-10-1901. Notario Manuel Fernández y García.

51 Testamento de Pedro Pele de Verges. 27-12-1768. Escribano Juan Lopez Salcedo.

52 Ibid.

53 Ibid.

54 Testamento de Francisco de la Puerta Lebrón, 17-4-1817. Escribano Antonio José Rodriguez.
} 
sociedades latinas que han recibido una clara influencia árabe, a la hora de ajustar las misas y el precio de las mismas, ello lo denota el justificante de Pedro Rodriguez y Gracia de 1837 "He recibido de D. Rafael Rodriguez la cantidad de trescientos veinte r.V. limosna de las misas de S. Vicente (30) qe. he aplicado por el alma de su Sr. padre D. Pedro, y además he aplicado las de S. Juan de Letrán (3) gratis...". 55

\section{OTRAS CONSIDERACIONES A TENER EN CUENTA}

Antes de llegar a las conclusiones finales, quisiera destacar algunas consideraciones que estimo importantes a tener en cuenta, la primera de ellas es que muchos de los testadores eran labradores, y ello se refleja en algunos testamentos por ciertos detalles a la hora de realizar donativos, un ejemplo claro es el de "Mando que el dia de mi fallecimiento y el de mi sepultura se repartan por mi Alvasea el pan que produzcan seis fanegas de trigo entre pobres mendigos y necesitados vergonzantes, dando a cada uno su quarterón con el encargo de que me encomienden a Dios, certificando averlo así cumplido y por que asi es mi voluntad."

Otra cuestión importante para hacer reflejar es la escasa ó nula aparición en los testamentos de donativos ó sufragios a favor de las hermandades tradicionales tanto de penitencia como de gloria que en Osuna estaban arraigadas en dicha época, algunas de las cuales han perdurado hasta nuestros dias. Tan solo hemos visto el encargo de varias misas en la capilla de una de ellas "Mando se apliquen por mi intención tres misas rezadas en el altar de Nuestra Señora de los Dolores en la Iglesia de la Victoria, abonándose seis reales por limosna"57: Existe también el caso de algunas hermandades desaparecidas en la actualidad, como ocurre con Juana Rodriguez Fernández que establece "Mando que mi cuerpo sea sepultado en la Iglesia del Convento Casa grande del Señor Santo Domingo y

55 Testamento de Pedro Rodriguez y Gracia, 26-6-1815. Escribano de Bargas y Rodriguez.

56 Testamento de Antonio María de la Puerta Zamora, 31-3-1860. Escribano Manuel de la Barrera.

57 Ibid. 
Boveda de la hermandad de Maria Santisima de la Aurora de que soy cofrade..." asegurando más adelante "Mando se haga a mi cuerpo el entierro que acostumbra la citada hermandad de nuestra Señora de la Aurora que tengo pagado..."58. Aunque en 1768 quedo reflejado " $Y$ es mi voluntad, asista a mi Entierro la Cofradia delas Animas del Rosario, que sale los lunes de Madrugada del convento del Señor san Francisco, de la que soy hermano, y asi mismo la del cirio de Nuestra Señora del Carmen, y de próxima convento de Señor Santo Domingo, de que igual mence soy hermano, alas que siendo estilo seles de la limosna que se haya acostumbrado con casos de igual clase." 59

Y por último en este apartado del aspecto puntual de las hermandades, me ha llamado sobremanera la atención la anotación que refleja el notario Manuel Fernández y Garcia haciendo referencia a la voluntad de su testadora la cual "También ordena que al trasladar su cadáver al Cementerio no se cubra la caja con el paño de ninguna hermandad a que pertenece la testadora."

También es reseñable la importancia que desde el siglo III se le ha dado a la cruz como símbolo de los cristianos y que continuaba catorce centurias después con la misma fuerza, como prueba de ello se puede leer "que asista a mi entierro la cruz curas y capellanes de la Santa Yglesia Collegial...”. ${ }^{61}$

\section{CONCLUSIONES}

Los testamentos han sido tradicionalmente un medio muy apropiado para regular el destino del patrimonio tras la muerte de su titular, pero se puede concluir que durante el periodo estudiado, los siglos XVIII y XIX, regulaban también y de una

58 Testamento de Juana Rodriguez Fernández. 3-5-1808. Escribano Antonio José Rodriguez.

59 Testamento de Pedro Pele de Verges. 27-12-1768. Escribano Juan Lopez Salcedo.

60 Testamento de Victoria de la Puerta y Zayas, 10-10-1901. Notario Manuel Fernández y García.

61 Testamento de Pablo Diez Hidalgo. 17-11-1702. Escribano Antonio Mancera de Roa. 
forma muy especial todo lo concerniente a la salvación del alma del testador. Se ha discutido entre los juristas la situación en la que queda la herencia a favor del alma del mismo tras su fallecimiento, estimándose que se trata de un patrimonio sin sujeto siendo lo que realmente se protege, no la figura del futuro titular en sí, sino la personalidad e interés del sujeto que se fue. El difunto desapareció como persona de derecho, pero queda un interés suyo que proteger (el interés espiritual) y éste es precisamente el que se ampara por la ley. Prueba de ello es que si desde la antigüedad estaba recogido por el derecho canónico, el Código Civil promulgado en 1889 también regula las disposiciones efectuadas a favor del alma y admite esta institución hereditaria de gran tradición en nuestra sociedad al disponer en el artículo 747: "Si el testador dispusiere del todo o parte de sus bienes para sufragios y obras piadosas en beneficio de su alma, haciéndolo indeterminadamente y sin especificar su aplicación, los albaceas venderán los bienes y distribuirán su importe, dando la mitad al Diocesano para que lo destine a los indicados sufragios y a las atenciones y necesidades de la Iglesia, y la otra mitad al Gobernador civil correspondiente para los establecimientos benéficos del domicilio del difunto, y en su defecto para los de la provincia".

En el apartado de las obras pías se observa una clara procedencia medieval en todos los sentidos, y se atisba con total nitidez la influencia que ha ejercido la Iglesia durante siglos para que los creyentes la consideraran amenazada por el Islam hasta incluso los primeros años del siglo XX, y prueba inequívoca de ello son las cantidades destinadas a dichos menesteres a través de los derechos de fábrica, el mantenimiento y custodia de los Santos Lugares de Jerusalén sin olvidar la redención de los cautivos cristianos.

En la elección de las obras pías por parte de los testadores se puede observar la evolución de los tiempos y la influencia que la sociedad ha recibido de la modernidad, y aunque continúan subsistiendo las antiguas motivaciones algunas de ellas cada vez más en desuso, llegando las personas a creer que la pobreza era un estado de perfección a la que se ha de contribuir con donativos de caridad, y dicho estamento tiene especial repercusión tras la llegada de las Hermanitas de los Pobres para atender el Asilo de Ancianos de Osuna que fue fundado en 1860. Otra prueba del devenir del 
tiempo era la donación de donativos tras la guerra de independencia ante la ocupación francesa para los que quedaron desprotegidos a causa de la misma, como eran las viudas y huérfanos de dicha contienda. De verdad que había calado en toda la comunidad el dicho popular de "como el agua apaga el fuego la limosna extingue el pecado", y prueba de ello es lo que refleja el testamento de Paula Rodriguez en el que "Mando que por mi fallecimiento se entreguen a mis albaceas dos mil r. Vn. Para que lo inviertan en limosnas y para el cumplimiento de esta clausula bastará que los mismos certifiquen haber cumplido con este encargo."62

Cuestión aparte y digna de mención es la cantidad de personas que vivian alrededor de la Iglesia, no solo en cuanto al número de sacerdotes ó clérigos, sino de todas aquellas que prestaban un servicio de forma directa ó indirecta tanto en los momentos acuciantes de salir de la vida terrenal, como también en el resto de servicios que prestaba la comunidad religiosa a toda la sociedad como bodas, bautizos, comuniones, confirmaciones y otros sacramentos. Se observa que en dicha época todavía la curia eclesiástica continuaba ejerciendo un gran dominio sobre la población y que en cierto sentido todavía tenía una fuerte influencia en la forma de pensar de los ursaonenses, incluso en el siglo XIX cuando su poder económico tras las desamortizaciones se había ido debilitando poco a poco por la pérdida de posesiones.

Para finalizar, podemos afirmar que la estructura de la sociedad que se creó en plena Edad Media y existía desde el siglo XI de un solo pueblo dividido en tres categorías según su cometido ó función social: los que rezaban, los que combatian y los que trabajaban ${ }^{63}$; continuó perdurando en cuanto a la labor de los clérigos se refiere hasta finales del siglo XIX en Osuna que fue cuando comenzó su decadencia.

62 Testamento de Paula Rodriguez de Gracia. 3-10-1834. Escribano Juan Bautista Pardillo.

63 Cf. J. L. GARCIA DE LA MATA CALVO. "Guia de estudio para la historia de la Iglesia antigua y medieval". Instituto Superior de Ciencias Religiosas San Isidoro y San Leandro de Sevilla. Octubre 2014. Página 103. 


\section{BIBLIOGRAFÍA}

- AGUILAR, Salvador, "Cien años de intensa labor", ABC de Sevilla, 25 de Octubre de 1981, página 17.

-A.G.S. Contaduría Generales. Leg. 768, fol. 408 vto.

- ALBADALEJO, Manuel y otros. Tomo XXXVII - Vol. $1^{\circ}$. Libro II. "De las donaciones y sucesiones". Leyes 148 a 252 de la Compilación o Fuero Nuevo de Navarra. Comentarios al Código Civil y Compilaciones Forales. Edersa, 1998.

- ALVAREZ SANTALO, León Carlos. "Osuna 1751 según las respuestas generales del catastro de Ensenada”. Editorial Tabapress. Madrid. 1992.

- BARRERA AYMERICH, Modesto V., "Religión y asistencia social en el antiguo régimen. Las mandas pias de los testadores de Castelló y Borriana durante los siglos XVII y XVIII". Revista de Historia Moderna, Número 16. 1990. Páginas 115-140.

- BAS (Biblioteca del Arzobispado de Sevilla). "por la Jurisdicción Eclesiástica y el Tribunal y Juzgado de los Testamentos de la Ciudad de Sevilla y su Arzobispado, sobre el conocimiento de las causas de los cumplimientos de los Testamentos". Signatura 42 - 93. Folleto $n^{\circ} 10$.

- CALDERÓN ALONSO, GERMÁN. "Un documento sobre cofradias en la villa de Osuna”. Fundación de Cultura García Blanco del Ayuntamiento de Osuna. Apuntes 2, número 4. 2004. Páginas 217-225.

- CALVO CRUZ, Mercedes; CASTRO PEREZ, Candelaria; GRANADOS SUAREZ, Sonia. "Análisis de una defunción en los siglos XVII y XVIII a través de las anotaciones contables que realizaba el colector parroquial". Tiempos Modernos. Revista electrónica de Historia Moderna, Volumen 5, Número 15, 2007.

- CANDAU CHACÓN, María Luisa. "Osuna y su clero en el siglo XVIIr". Del libro "Osuna entre los tiempos medievales y modernos (siglos XIII - XVIII). Juan José Iglesias Rodriguez y Manuel García Fernandez. Universidad de Sevilla. 1995. Páginas 389-412.

- CORREAS, Pilar. "Poblaciones españolas de más de 5000 habitantes entre los siglos XVII y XIX”. Revista de Demografia Histórica. 1988.

- DELGADO ABOUZA, Francisco Manuel, "La ermita de santa Ana y el intento de restauración de la orden hospitalaria de san Juan de Dios en Osuna". Apuntes 2, no 4, (2004). Páginas 135-169. 
- ESTEVEZ SANTAMARÍA, María del Pilar, "Practicas Testamentarias en el Madrid del siglo XVI: Norma y Realidad". Conferencia impartida en las IX Jornadas Científicas sobre Documentación "La muerte y sus testimonios escritos" celebradas en la Facultad de Geografia e Historia de la Universidad Complutense de Madrid durante los dias 3, 10 y 17 de marzo de 2010.

- FERNÁNDEZ-PRIDA MIGOYA, Francisco. "La sucesión hereditaria y el juicio divisorio". Editorial Lex Nova-Thomson Reuters, noviembre 2012.

- GARCIA DE LA MATA CALVO, José Luís. "Guía de estudio para la historia de la Iglesia antigua y medieval". Instituto Superior de Ciencias Religiosas San Isidoro y San Leandro de Sevilla. Octubre 2014.

- G. DE VALDEAVELLANO, Luis, "La cuota de libre disposición en el derecho hereditario en León y Castilla en la Alta Edad Media", publicado en el Anuario de Historia del Derecho Español, XI, Madrid (1932), páginas 129-176.REAL ACADEMIA ESPAÑOLA, "Nueva Enciclopedia Larousse”, Tomos 1, 7, 8, 14 y 19, Planeta, Barcelona 1980.

- GUTIERREZ NUÑEZ, Francisco Javier. "Origen y fundación del Colegio de la Compañía de Jesús en Osuna en el primer tercio del siglo XVII". Fundación de Cultura García Blanco del Ayuntamiento de Osuna. Apuntes 2, número 5. 2007. Páginas 119-184.

- GUTIERREZ NUÑEZ, Francisco Javier. "Una visión cultural de los testamentos ursaonenses de finales del siglo XVIII". Fundación de Cultura García Blanco del Ayuntamiento de Osuna. Apuntes 2, número 4. 2004. Páginas 69-105.

- LEDESMA GALVEZ, Francisco. "Las murallas de Osuna.” Fundación El Monte. Sevilla, 2003

- LLAMAZAREZ RODRIGUEZ, Eduardo."Juan de Peñalosa y Sandoval. Enfermedad, testamento, muerte y almoneda". Tierras de León: Revista de la Diputación Provincial. Volumen 20. Número 41. 1980. Páginas 89-96.

- MALDONADO Y FERNÁNDEZ DEL TORCO, José, "Herencias a favor del alma en Derecho español", ed. <<Revista de Derecho Privado>>, Madrid, 1944.

- MARTÍNEZ SANZ, J. "Una aproximación a la documentación de los archivos parroquiales de España". Hispania n 162, páginas 169-194. 1986. 
- MIURA ANDRADES, Jose María. "Las órdenes religiosas en Osuna y su entorno hasta finales del siglo XVI". Del libro "Osuna entre los tiempos medievales y modernos (siglos XIII - XVIII). Juan José Iglesias Rodriguez y Manuel García Fernandez. Universidad de Sevilla. 1995. Páginas 337-388.

- MORENO DE SOTO, Jaime, "La configuración barroca de Osuna", Cuadernos de los Amigos de los Museos, n 12 (1910), páginas 39-47.

- MORIN, Edgar, “El hombre y la muerte”. Barcelona, Kairós, 1974.

- MÜNZER, Jerónimo. “Viaje por España y Portugal”. Editorial Polifemo. Madrid, 1991, página 151.

- ORLANDIS, José. "Sobre la elección de sepultura en la España medieval", 1950.

- PALACIOS BAÑUELOS, Luis, "Seis escenarios de la historia. Osuna. Escenario vital de Rodriguez Marín”. Páginas 263 a 282. Editorial Dykinson. 2007.

- RODRIGUEZ SÁNCHEZ, Ángel, “Morir en Extremadura”, 1980.

- REAL ACADEMIA DE LA LENGUA. "Nueva Enciclopedia Larousse”. Tomos 1, 7, 8, 14 y 19. Planeta. Barcelona 1980.

- RIVERA Y AVALOS, Juan J. "El “Quijote“y la Universidad de Osuna. Ecos del libro inmortal”. ABC de Sevilla.

- RODRIGUEZ-SAN PEDRO BEZARES, Luis E. “Atmosfera universitaria en Cervantes". Universidad de Salamanca. 2006.

- SALAS, Nicolás. "Sevilla: crónicas del siglo XX". Volumen 1. Universidad de Sevilla. 1991.

- SANCHEZ HERRERO, José. "Osuna. La villa y su gobierno ducal. La Iglesia y la religiosidad (1695-1739)". Del libro "Osuna entre los tiempos medievales y modernos (siglos XIII - XVIII). Juan José Iglesias Rodriguez y Manuel García Fernandez. Universidad de Sevilla. 1995. Páginas 363-388.

- SORIA MEDINA, Enrique. "La sociedad económica de amigos del pais de Osuna". Publicaciones de la Excma. Diputación Provincial de Sevilla. Sección Historia, serie $1^{\circ}$ número 8. Sevilla 1975.

- http://es.wikipedia.org/wiki/Peseta [Consulta 15-11-2014]. 


\section{ANEXOS}

Anexo $n^{\circ} 1$ : Generalidades

Anexo $n^{\circ} 2$ : Entierros

Anexo $\mathrm{n}^{\circ}$ 3: Misas solicitadas y celebradas

Anexo $n^{\circ}$ 4: Hermandad Sacramental

Anexo $n^{\circ}$ 5: Denominaciones de la Hermandad Sacramental

Anexo $n^{\circ}$ 6: Hermandad de la Santa Caridad

Anexo $n^{\circ}$ 7: Custodia de los Santos Lugares de Jerusalén

Anexo $\mathrm{n}^{\circ}$ 8: Otras obras pías8

\section{SINOPSIS DE LOS ANEXOS}

En estos 8 anexos se puede resumir los datos extraídos de los 24 documentos estudiados en la realización de este trabajo. Pero a la hora de analizarlos hay que tener en cuenta varias cuestiones:

- Algunas páginas no se pueden leer con claridad y nitidez.

- No todos los documentos poseen los justificantes de haberse realizado las demandas de última voluntad del testador.

- En los documentos que poseen dichos justificantes, pueden faltar algunos de ellos (son recibís en hojas anexadas).

- Algunos de los documentos analizados son copias, sobre todo los de los últimos años.

Los anexos comprenden las siguientes cuestiones:

- Anexo $n^{\circ}$ 1: Generalidades. Incluye la fecha de realización del documento, el testador, el tipo de documento, el escribano 
ó notario que lo redacta, los albaceas solidarios y algunas observaciones a tener en cuenta.

- Anexo $\mathrm{n}^{\circ}$ 2: Entierros. Incluye la fecha de redacción del documento, el testador, el templo donde se ha realizado el entierro y otros gastos del mismo, la fecha del recibí y el firmante del mismo, el coste y un apartado de observaciones.

- Anexo $n^{\circ} 3$ : Misas solicitadas y celebradas. Incluye además de la fecha de realización del documento y el testador, el número de misas solicitadas en el documento, los templos donde se realizan las mismas así como el número, la fecha y el firmante del recibí, el importe del donativo y otras observaciones a tener en cuenta.

- Anexo $\mathrm{n}^{\circ}$ 4: Archicofradía Sacramental. Figuran el testador y la fecha del documento, el justificante y el miembro de la Hermandad que recibe el donativo así como su cargo en la misma, y por último un apartado de observaciones.

- Anexo $n^{\circ}$ 5: Denominaciones de la Archicofradía Sacramental. Junto a la fecha de realización del documento y del testador, se reseñan las distintas denominaciones con las que aparece dicha Hermandad, tanto en el propio documento así como en el recibí de la limosna.

- Anexo $n^{\circ}$ 6: Hermandad de la Santa Caridad. Igual que en el anexo $n^{\circ} 4$ pero de esta cofradía.

- Anexo n ${ }^{\circ}$ 7: Para la custodia de los Santos Lugares de Jerusalén. Similar al anterior.

- Anexo $n^{\circ}$ 8: Otras obras pías. Similar a los anteriores señalando el destino del donativo en cuestión. 


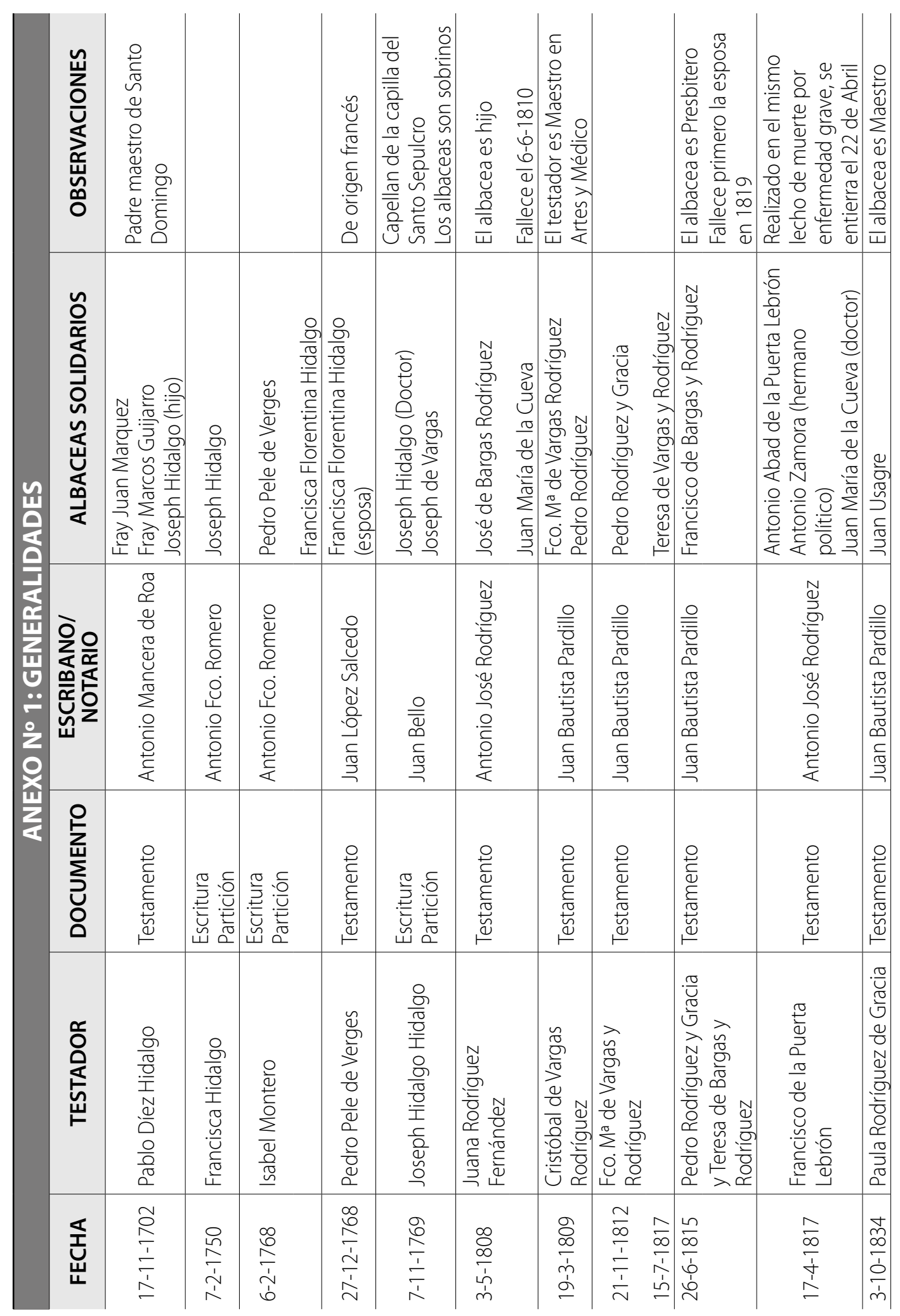




\begin{tabular}{|c|c|c|c|c|c|c|c|c|c|c|c|c|c|}
\hline 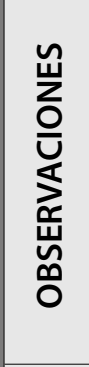 & & 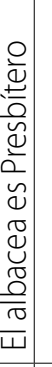 & & 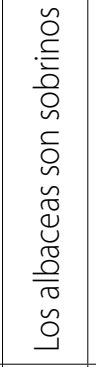 & 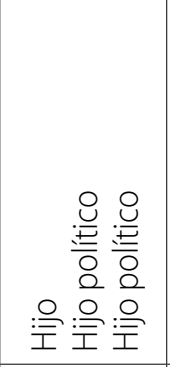 & & & 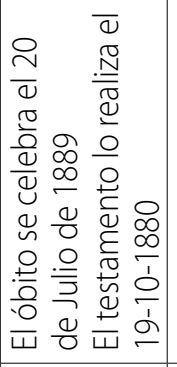 & 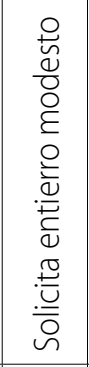 & 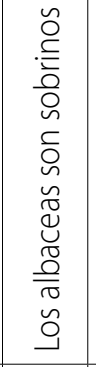 & & & 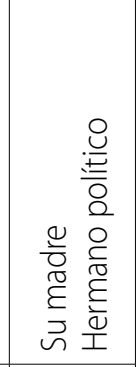 \\
\hline 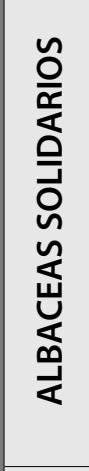 & 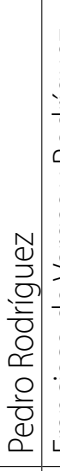 & 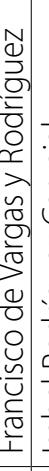 & 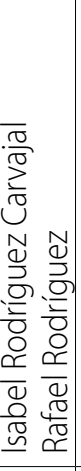 & 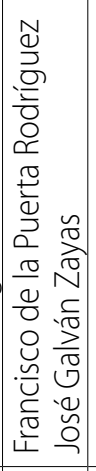 & 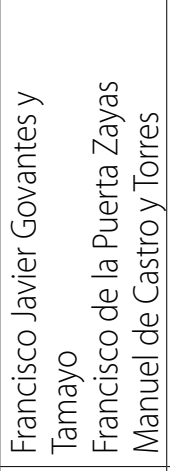 & 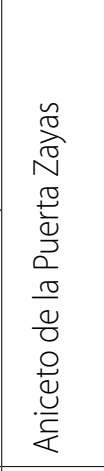 & 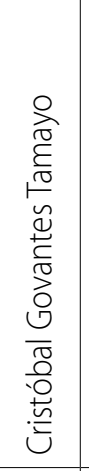 & 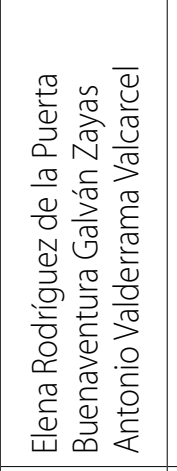 & 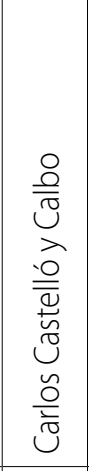 & 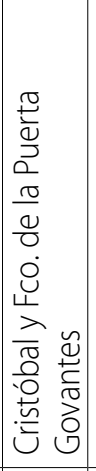 & 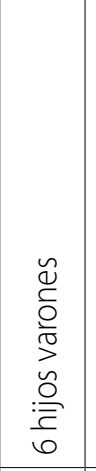 & 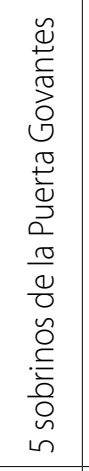 & 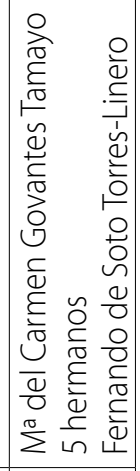 \\
\hline 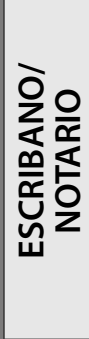 & 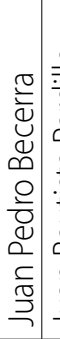 & 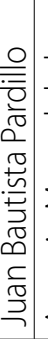 & 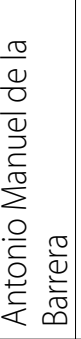 & 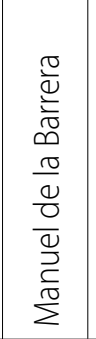 & 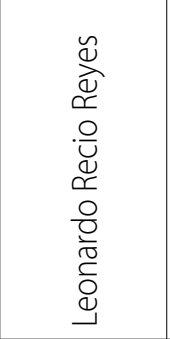 & 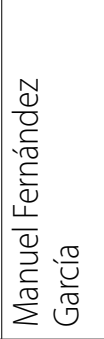 & & 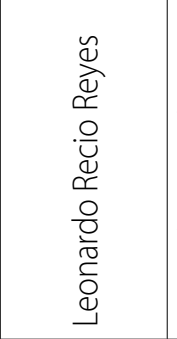 & 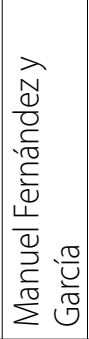 & 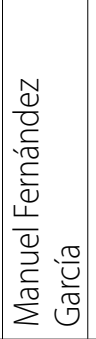 & 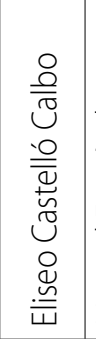 & 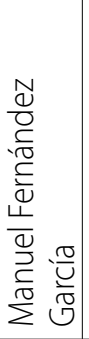 & 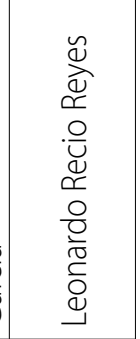 \\
\hline 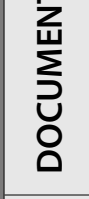 & $\begin{array}{l}:= \\
\overline{\bar{z}} \\
\overline{0} \\
\end{array}$ & 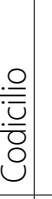 & 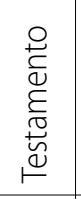 & 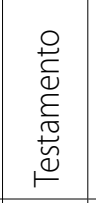 & 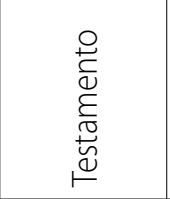 & 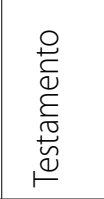 & & 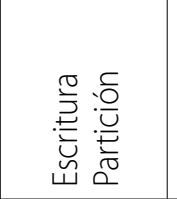 & 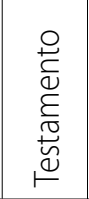 & 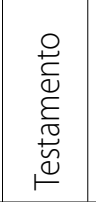 & 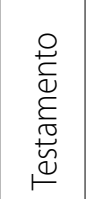 & 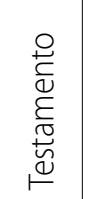 & 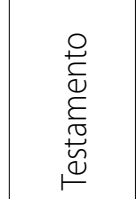 \\
\hline 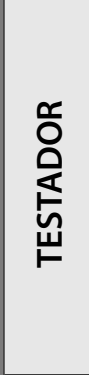 & 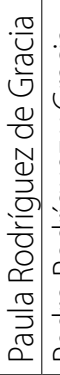 & 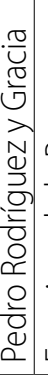 & 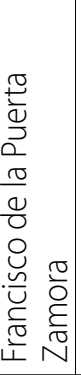 & 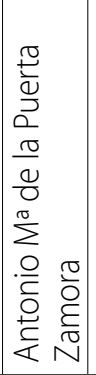 & 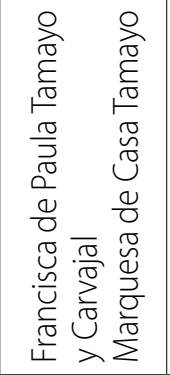 & 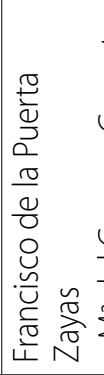 & 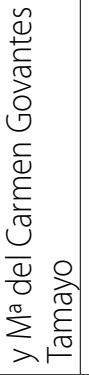 & 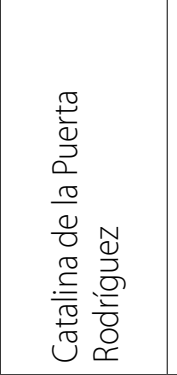 & 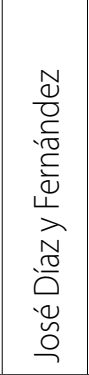 & 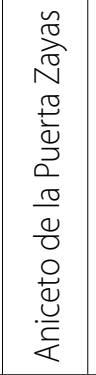 & 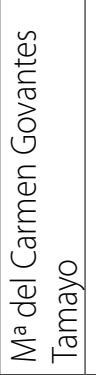 & 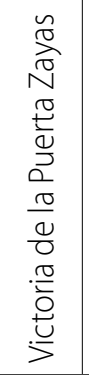 & 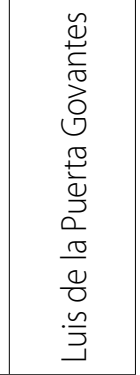 \\
\hline 㜽 & 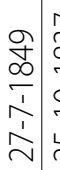 & 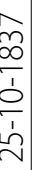 & $\begin{array}{l}\text { Fै } \\
\infty \\
\infty \\
0 \\
i n \\
i n\end{array}$ & $\begin{array}{l}\otimes \\
\infty \\
\frac{\infty}{1} \\
\frac{1}{m}\end{array}$ & 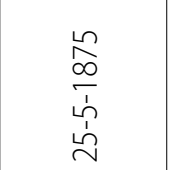 & $\begin{array}{l}\frac{\hat{0}}{\infty} \\
\frac{\dot{1}}{\overline{1}} \\
\frac{1}{\sim}\end{array}$ & & 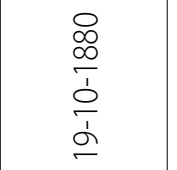 & $\begin{array}{l}\infty \\
\infty \\
\infty \\
\frac{1}{1} \\
\hat{\jmath}\end{array}$ & $\begin{array}{l}\infty \\
\infty \\
\infty \\
\infty \\
\vdots \\
\vdots \\
\vdots\end{array}$ & 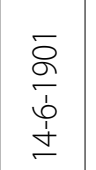 & $\begin{array}{l}\frac{\overline{8}}{0} \\
\frac{0}{0} \\
\frac{1}{0}\end{array}$ & 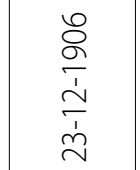 \\
\hline
\end{tabular}




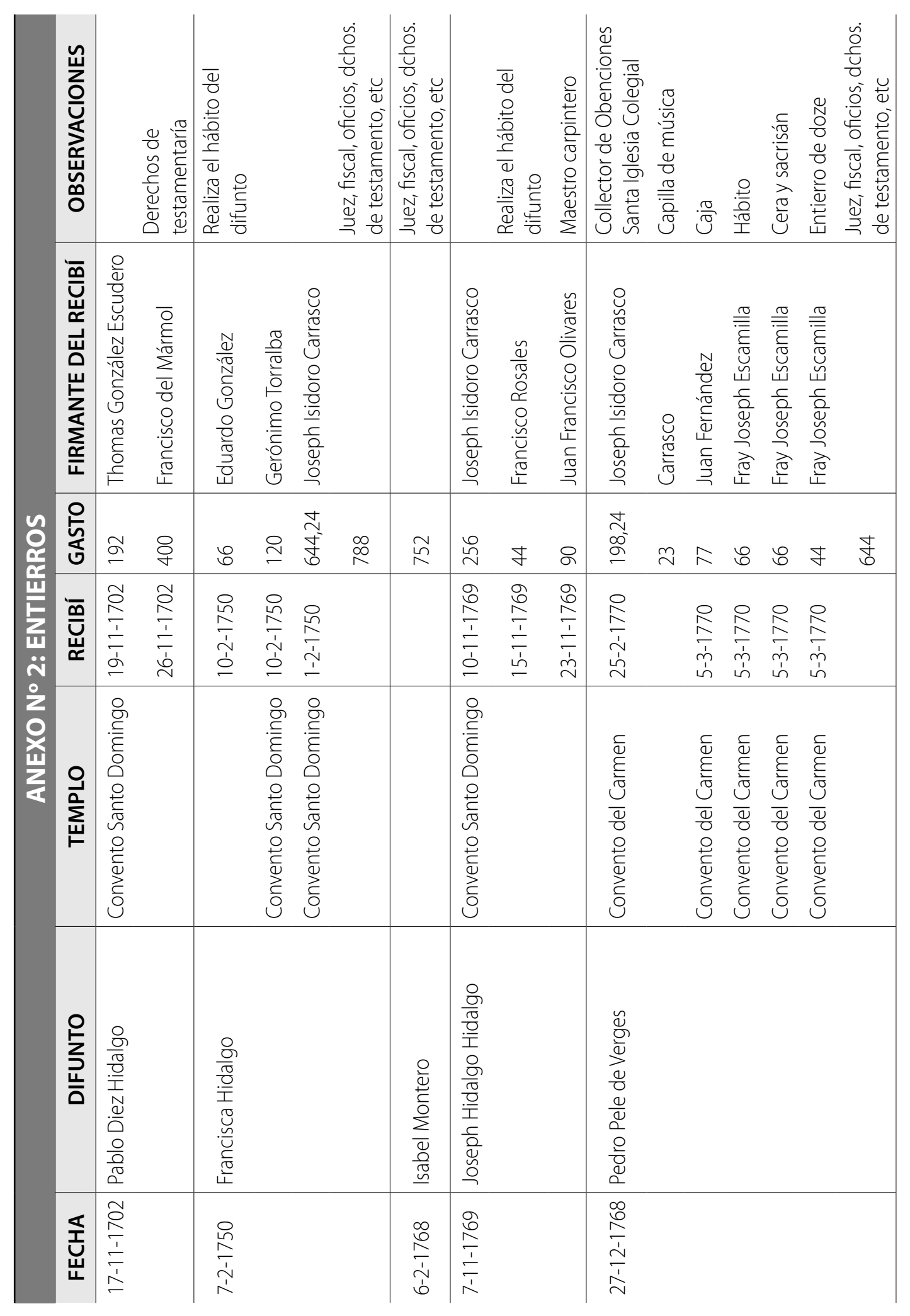




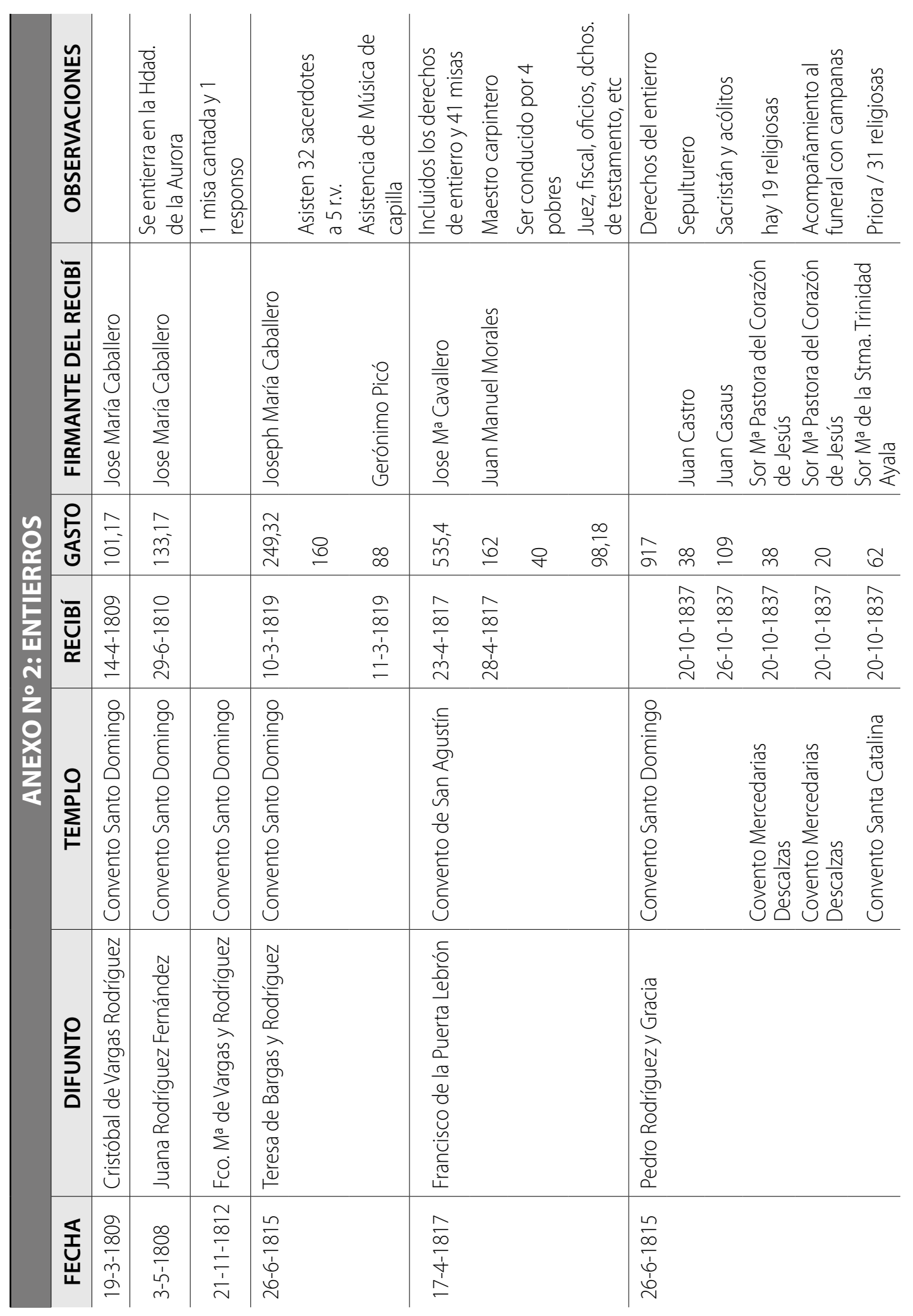


Carlos de la PUERTA LOMELINO

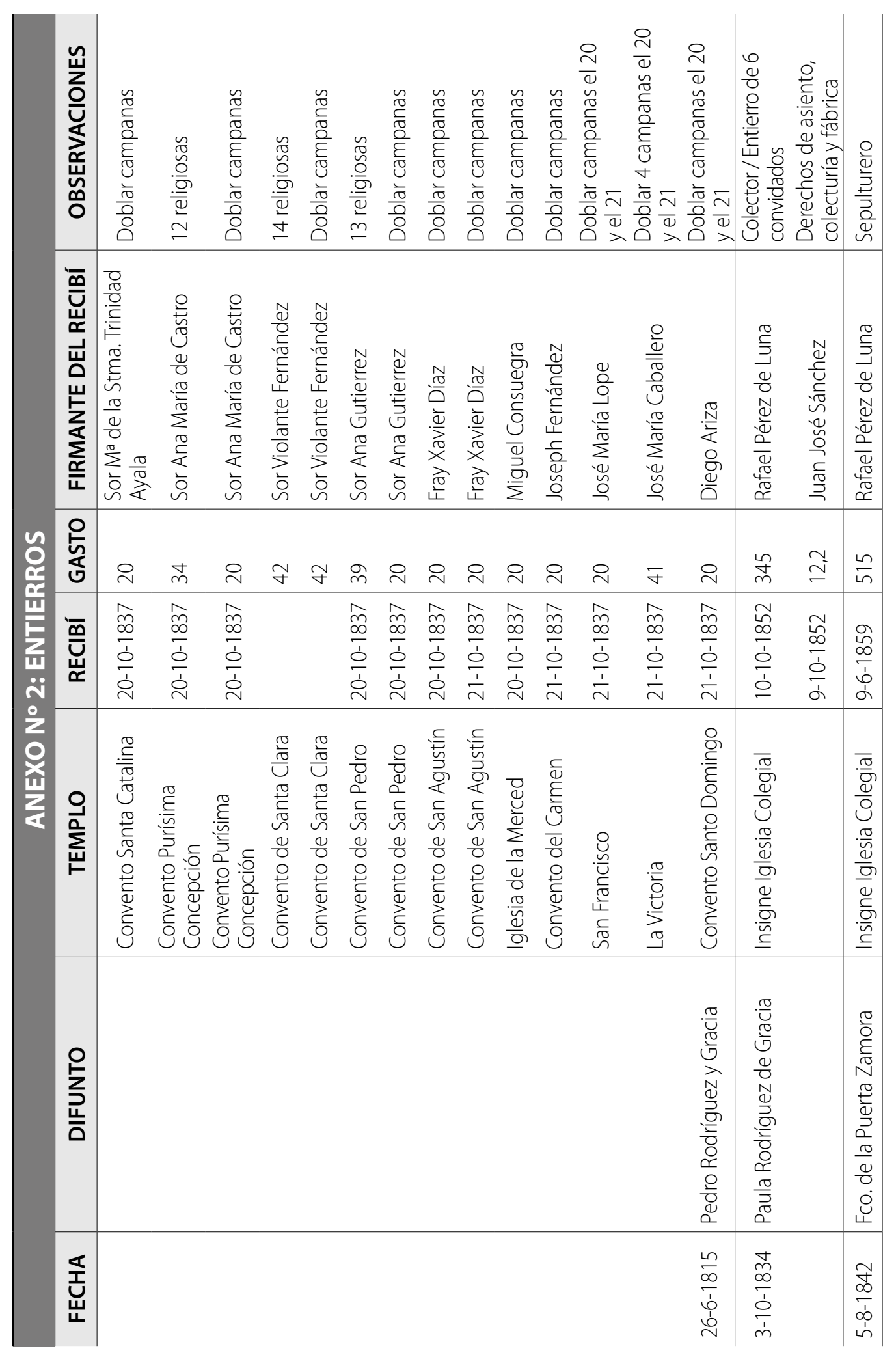




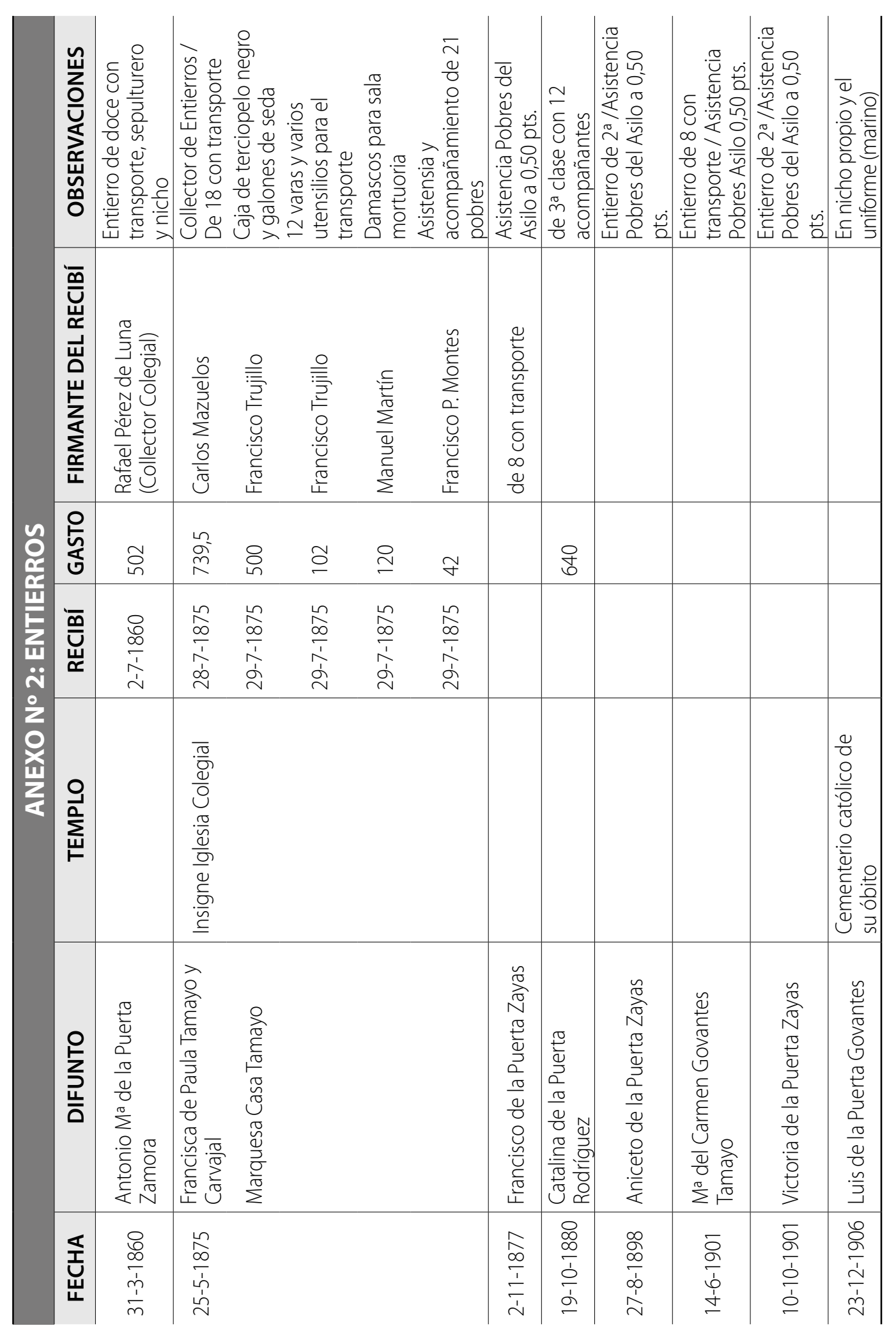




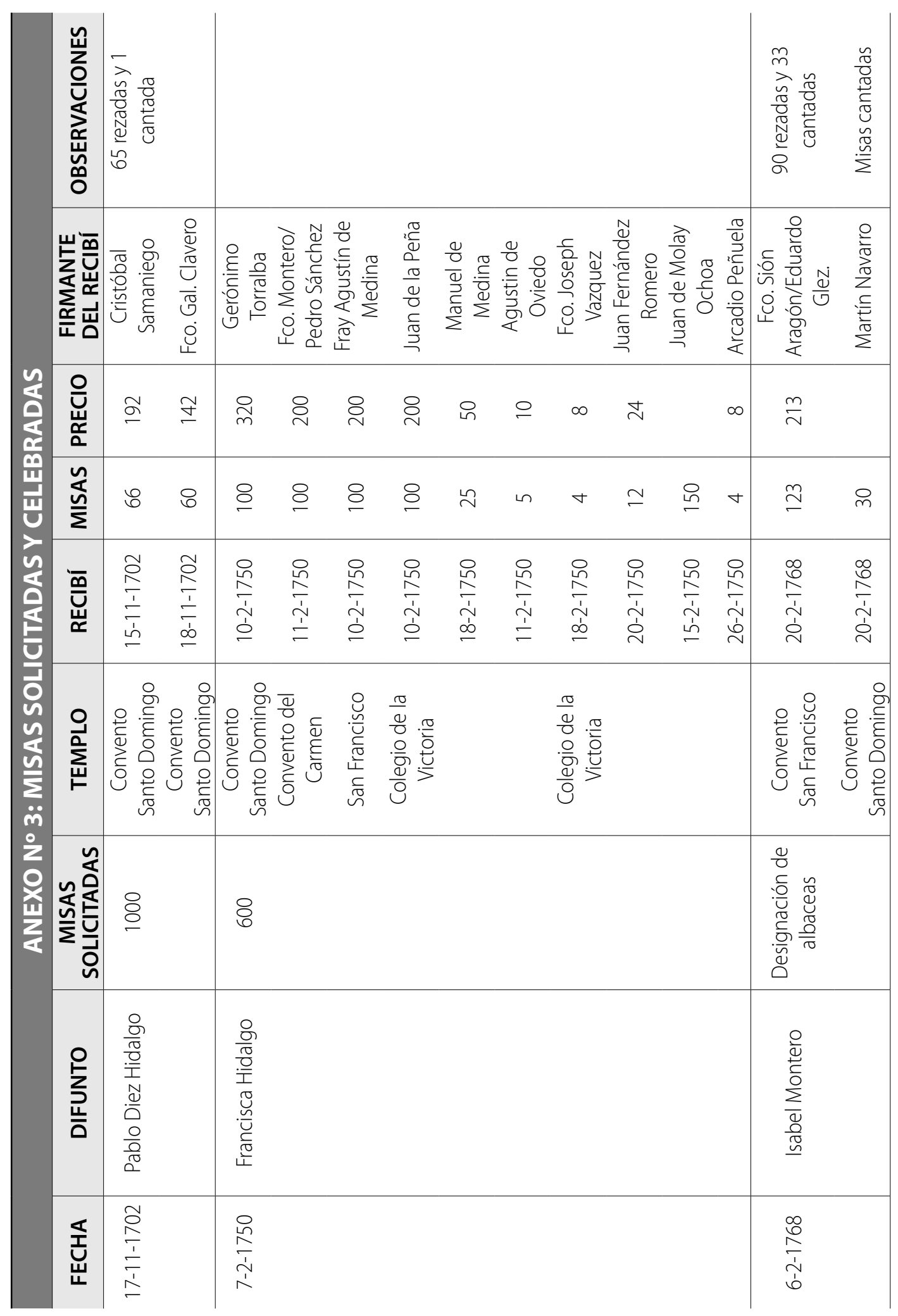




\begin{tabular}{|c|c|c|c|c|c|}
\hline 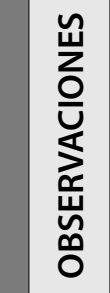 & 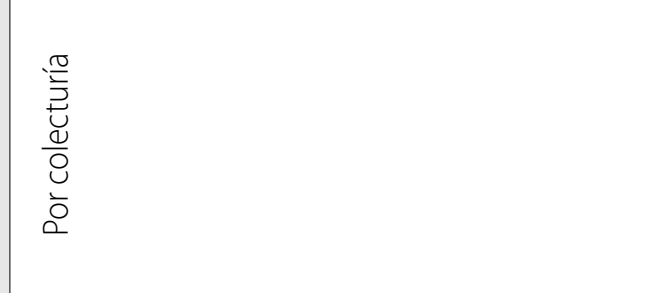 & 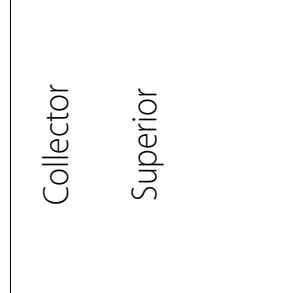 & 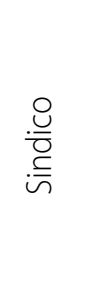 & 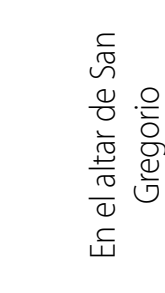 & \\
\hline 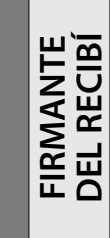 & 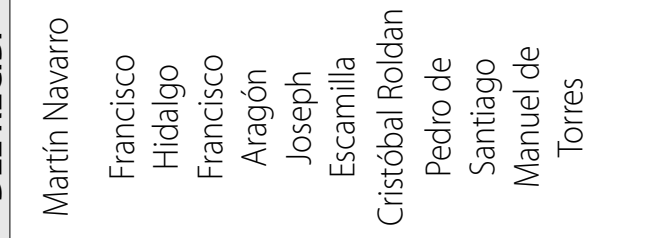 & 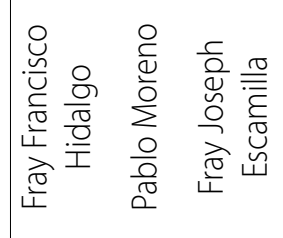 & 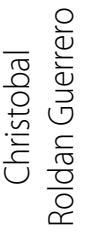 & 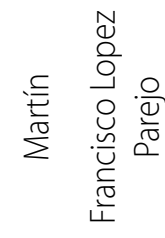 & 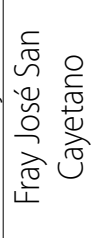 \\
\hline 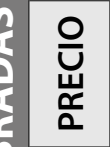 & A & 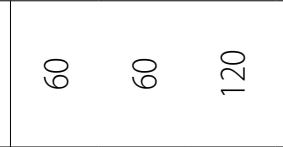 & 8 & $\stackrel{n}{\wedge}$ & $\infty$ \\
\hline 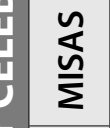 & 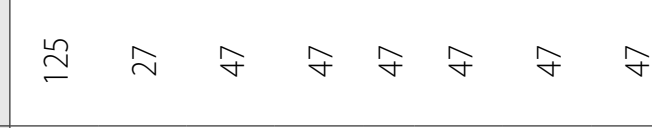 & ㄱ & $\stackrel{\lambda}{2}$ & $\stackrel{\sim}{\sim}$ & $\approx$ \\
\hline 产 & 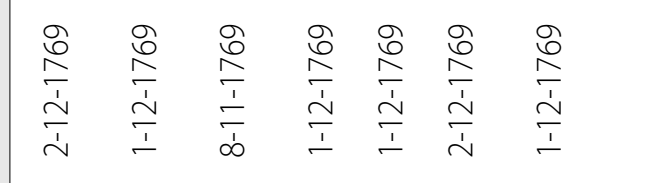 & 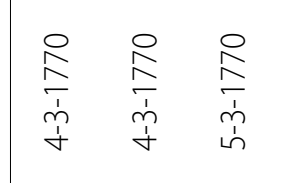 & 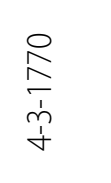 & 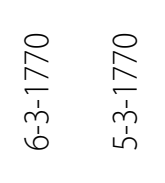 & 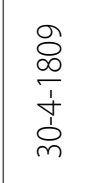 \\
\hline 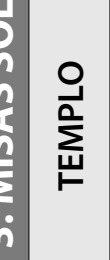 & 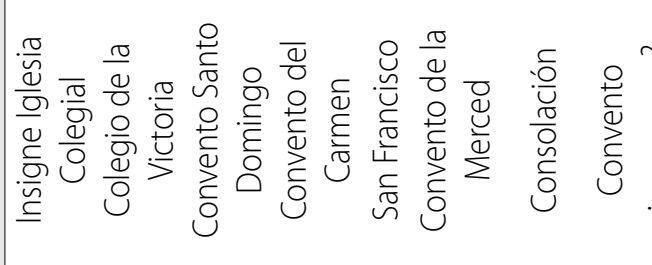 & 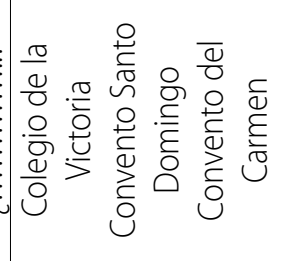 & 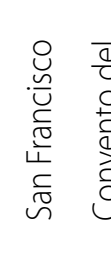 & 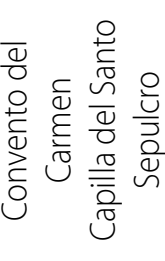 & \\
\hline 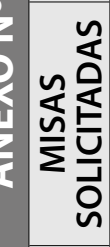 & \& & 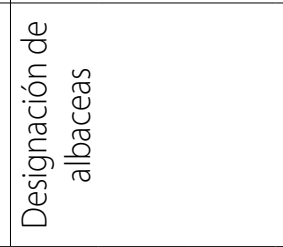 & & & ஓ \\
\hline 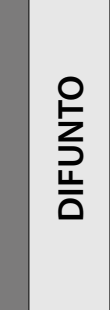 & 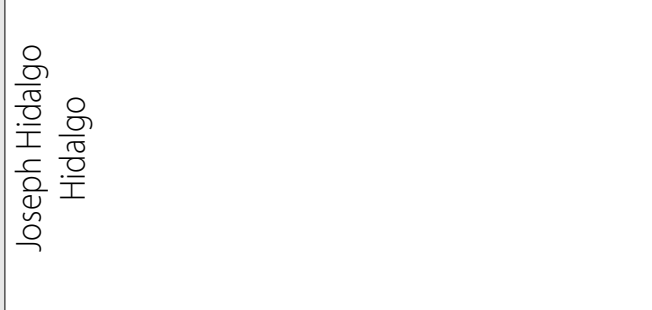 & 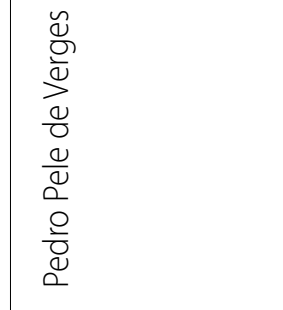 & & & 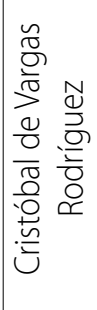 \\
\hline 耍 & $\begin{array}{l}\frac{0}{0} \\
\stackrel{2}{\vdots} \\
\frac{1}{1}\end{array}$ & 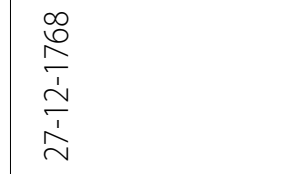 & & & 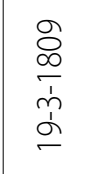 \\
\hline
\end{tabular}




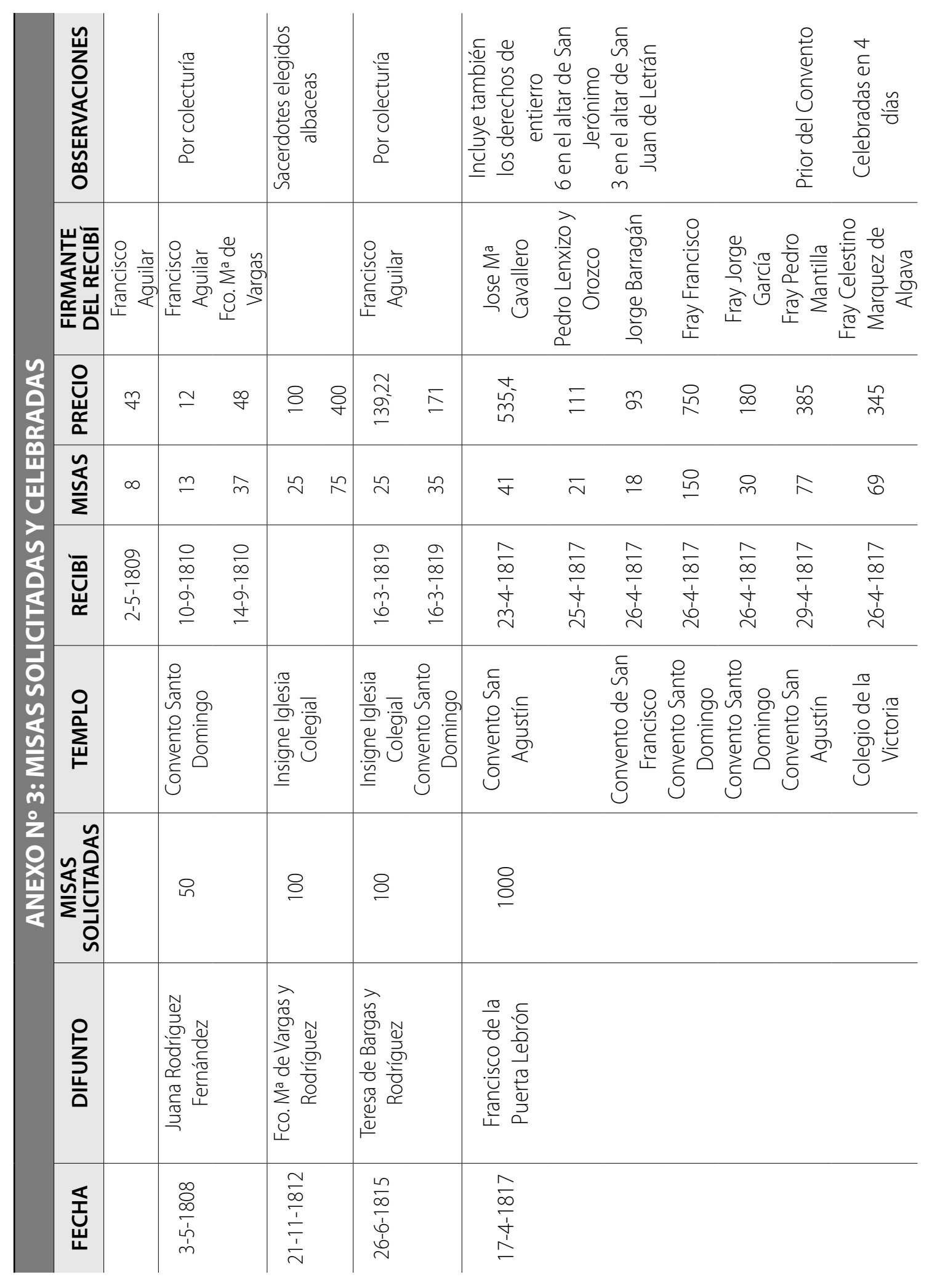




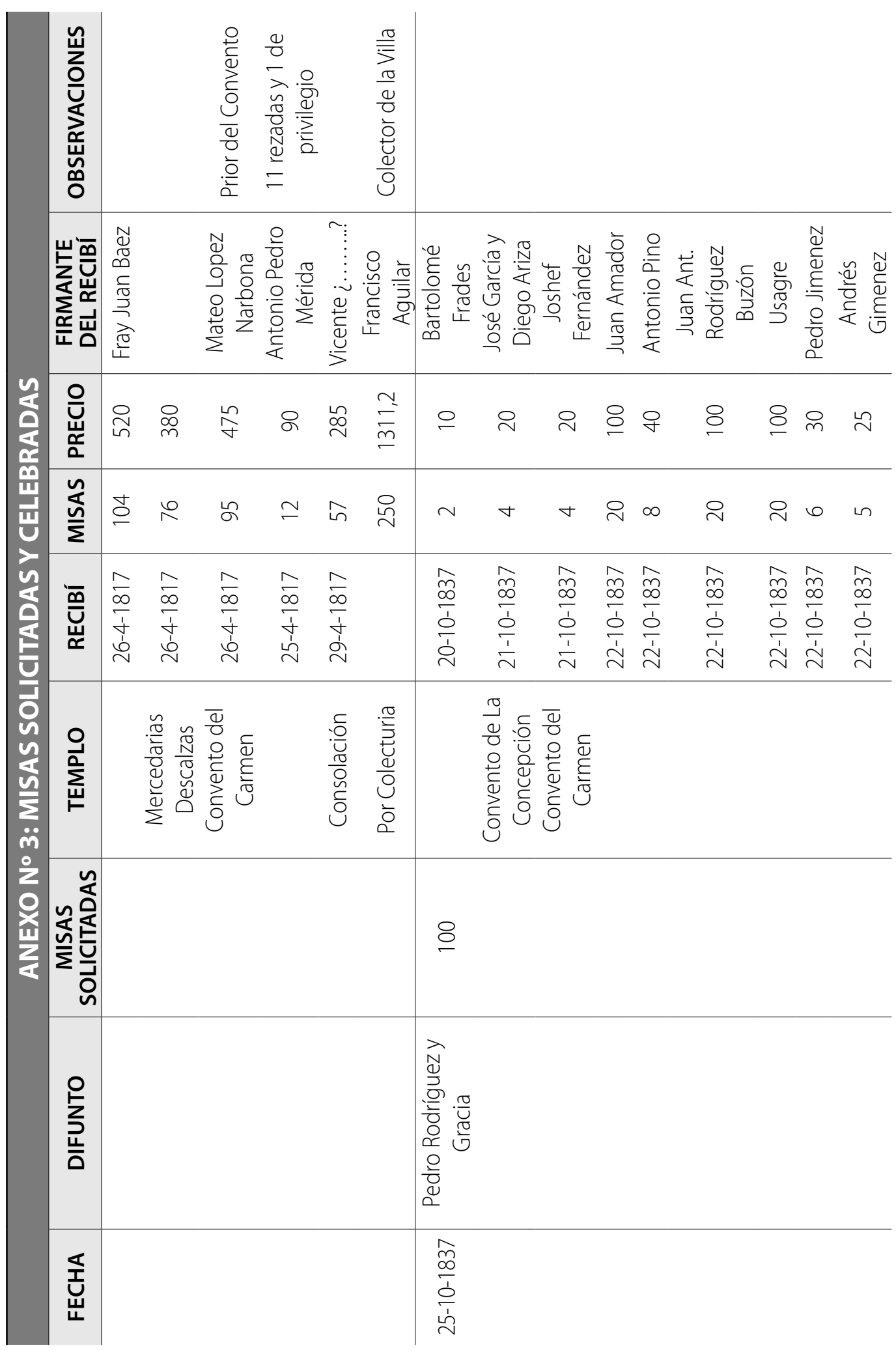




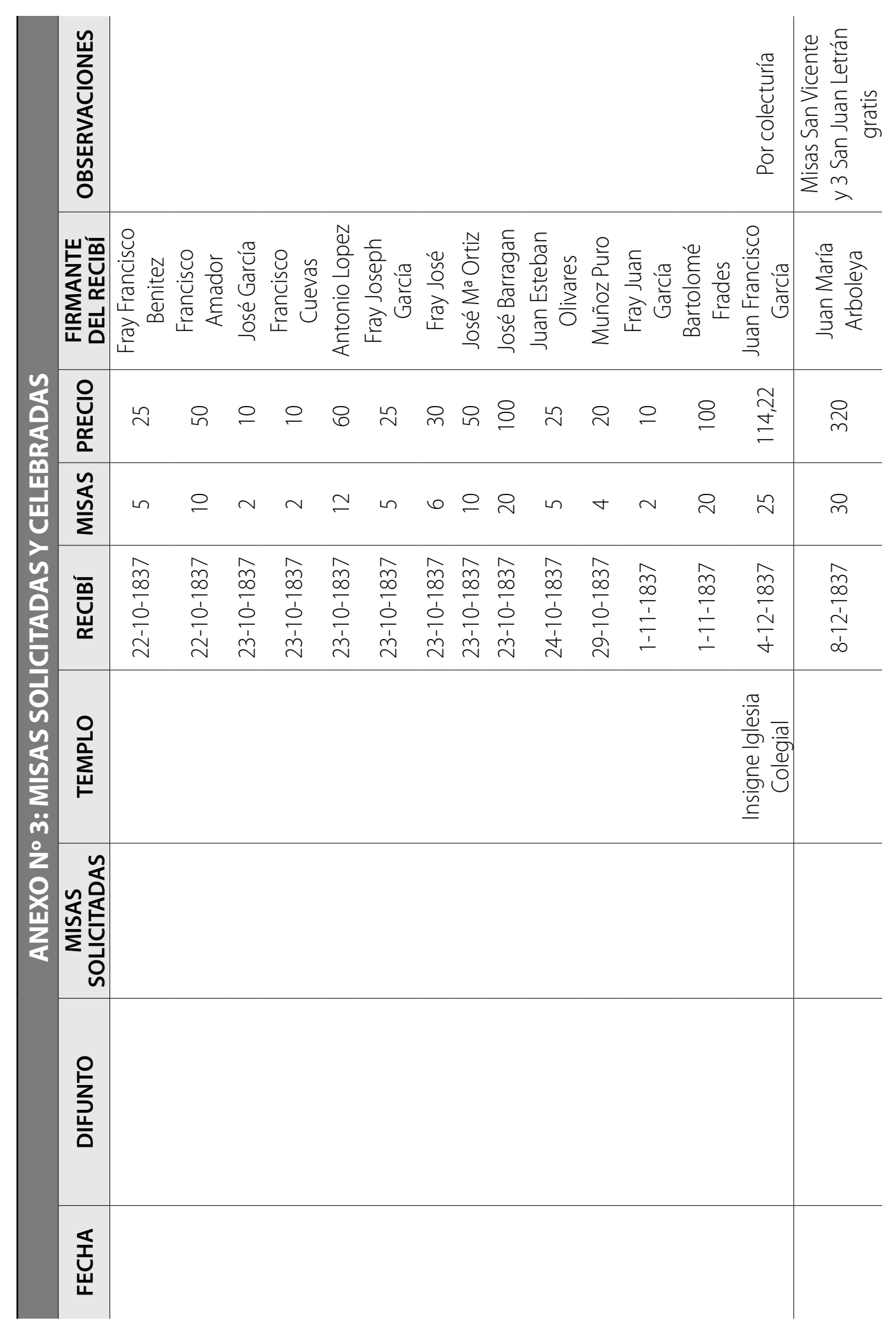




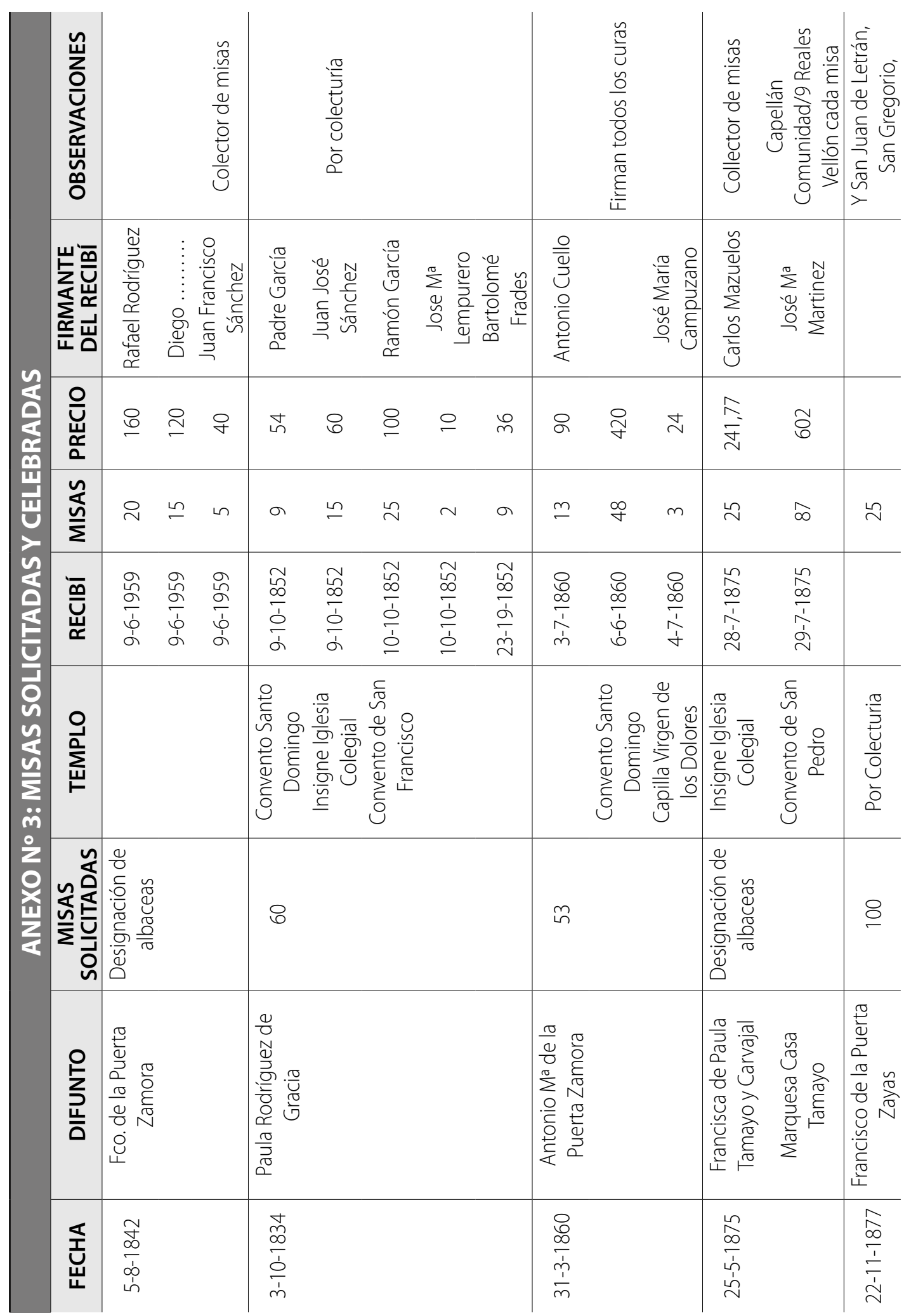




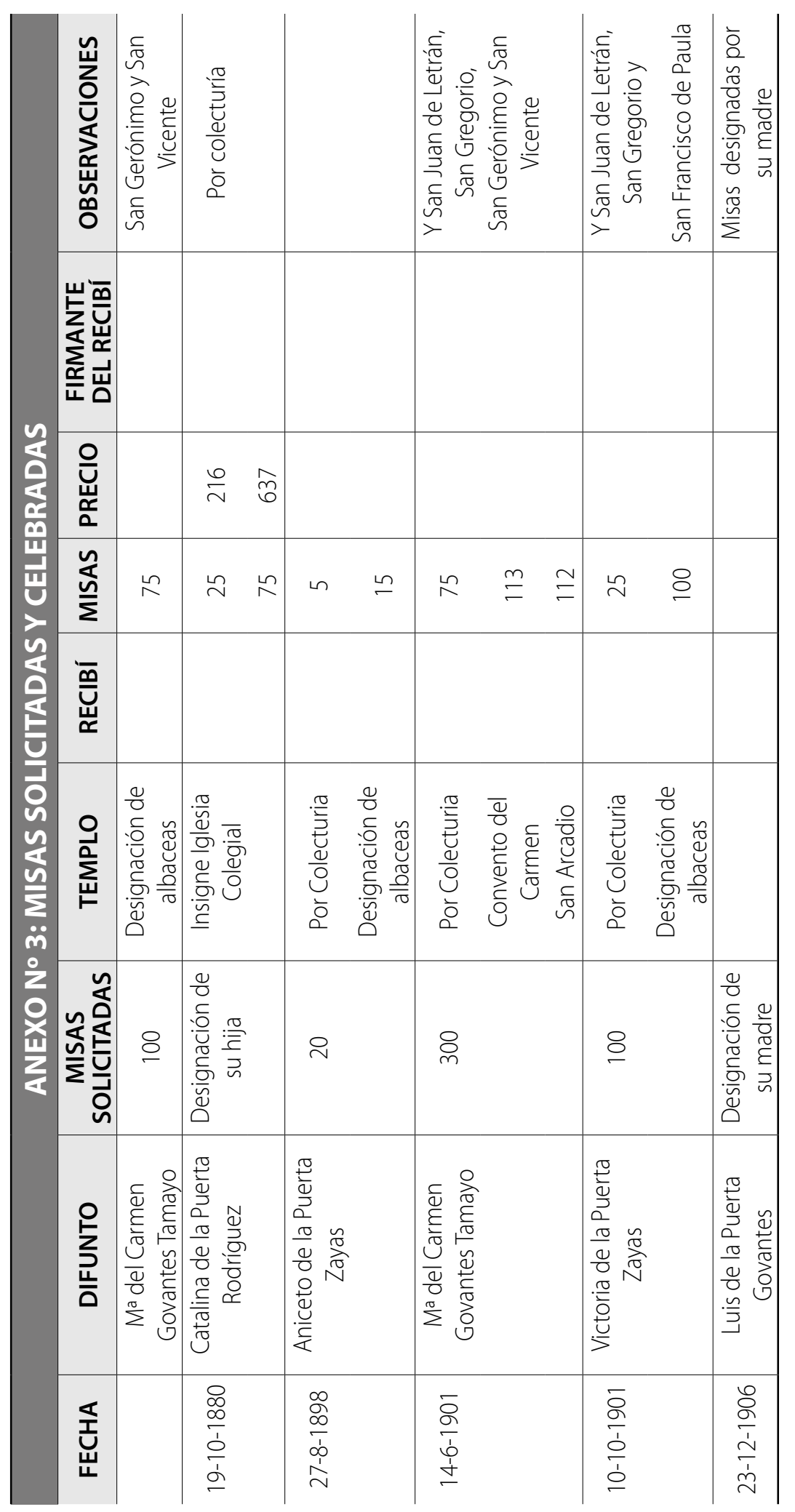




\begin{tabular}{|c|c|c|c|c|c|c|c|c|c|c|c|c|c|c|c|c|c|c|c|c|c|}
\hline 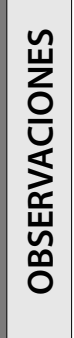 & & & & & & & & & & & 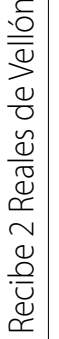 & & & 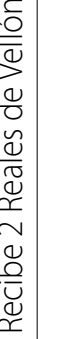 & & & & & & & \\
\hline 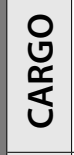 & $\begin{array}{l}\frac{0}{0} \\
\frac{0}{3} \\
\frac{0}{0} \\
0\end{array}$ & $\begin{array}{l}\frac{0}{0} \\
\frac{0}{5} \\
\frac{0}{0} \\
\frac{0}{0}\end{array}$ & $\begin{array}{l}\frac{0}{0} \\
\frac{0}{5} \\
\frac{0}{0} \\
\frac{0}{0}\end{array}$ & $\begin{array}{l}\frac{0}{0} \\
\frac{0}{5} \\
\frac{0}{0}\end{array}$ & & & & $\begin{array}{l}\overline{0} \\
\frac{0}{0} \\
\overline{0} \\
\\
0\end{array}$ & & & & & & & & & & & & & \\
\hline 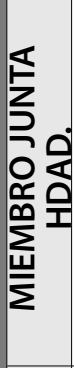 & 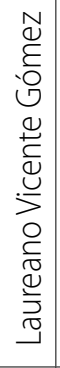 & 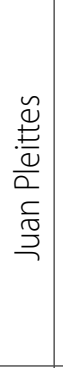 & 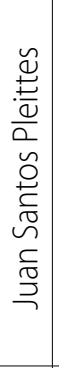 & 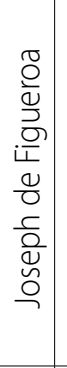 & 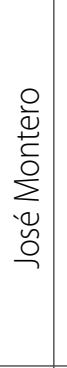 & 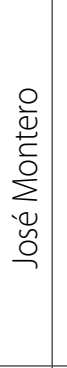 & & $\begin{array}{l}\frac{0}{0} \\
\frac{0}{2} \\
0 \\
\frac{0}{0} \\
\frac{0}{0} \\
\frac{5}{4} \\
\sqcup\end{array}$ & 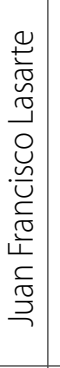 & 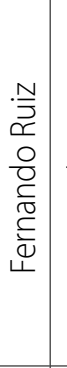 & 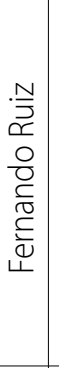 & 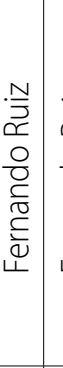 & 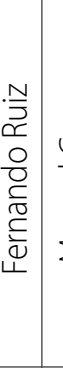 & 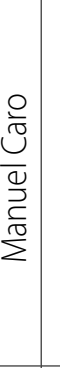 & & & & & & & \\
\hline 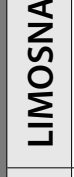 & $\stackrel{\grave{\sim}}{\sim}$ & $\stackrel{\stackrel{a}{\sim}}{\sim}$ & $\stackrel{\vec{i}}{\sim}$ & 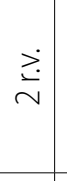 & $\stackrel{\stackrel{2}{\longrightarrow}}{\longrightarrow}$ & 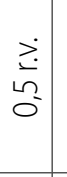 & $\stackrel{\vec{i}}{\sim}$ & $\stackrel{\vec{i}}{\sim}$ & $\stackrel{\geq}{\vec{\forall}}$ & 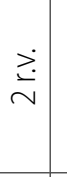 & $\begin{array}{l}\geq \\
\geq \\
2 \\
0\end{array}$ & $\stackrel{i}{\sim}$ & $\stackrel{\vec{\Sigma}}{\sim}$ & 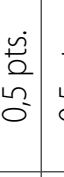 & 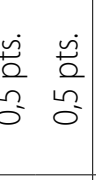 & 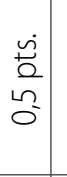 & 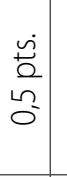 & 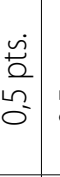 & 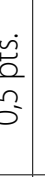 & $\begin{array}{l}\vec{n} \\
\stackrel{2}{v}\end{array}$ & $\frac{\stackrel{n}{0}}{\stackrel{0}{\sim}}$ \\
\hline 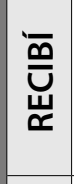 & 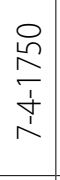 & $\mid \begin{array}{l}\infty \\
o \\
\\
\hat{\alpha} \\
\grave{n} \\
\sim\end{array}$ & $\begin{array}{l}\frac{9}{D} \\
\frac{1}{\dot{v}} \\
\stackrel{\dot{\sim}}{\sim}\end{array}$ & 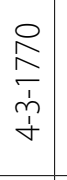 & 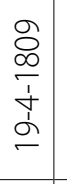 & $\begin{array}{l}\frac{0}{\infty} \\
\infty \\
\bar{\alpha} \\
\frac{1}{\sim}\end{array}$ & & $\begin{array}{l}\frac{\sigma}{\infty} \\
\infty \\
\dot{1} \\
\stackrel{n}{n} \\
\stackrel{n}{n}\end{array}$ & 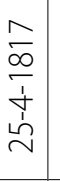 & 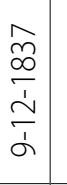 & 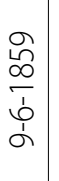 & $\begin{array}{l}\tilde{N} \\
\infty \\
\frac{1}{0} \\
\frac{1}{ \pm} \\
=\end{array}$ & $\begin{array}{l}8 \\
8 \\
\infty \\
\frac{1}{1} \\
\dot{\gamma}\end{array}$ & 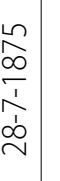 & & & & & & & \\
\hline 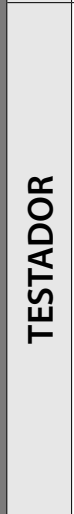 & 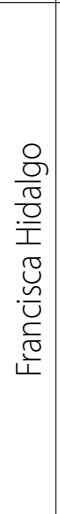 & 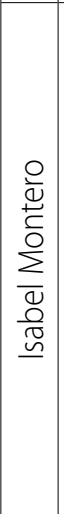 & 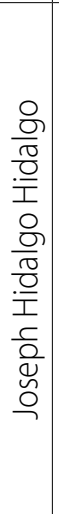 & $\begin{array}{l}\breve{d} \\
\frac{v}{d} \\
\frac{d}{0} \\
\frac{d}{d} \\
\frac{0}{0} \\
\frac{0}{d} \\
\alpha\end{array}$ & 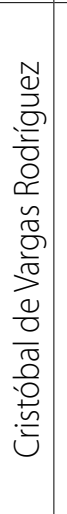 & 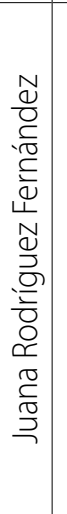 & 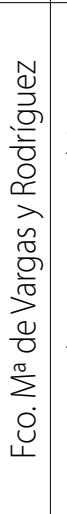 & 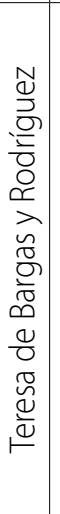 & 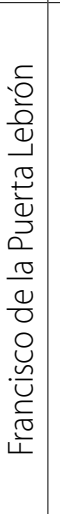 & 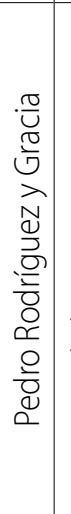 & 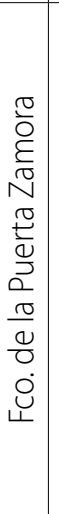 & 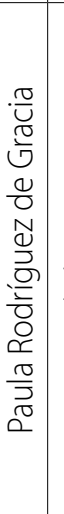 & 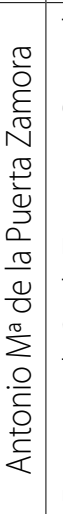 & 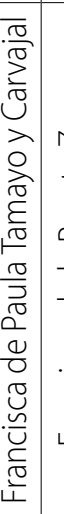 & 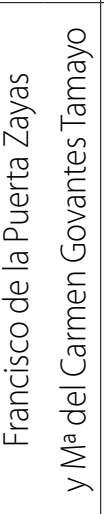 & 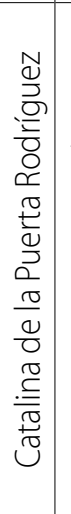 & 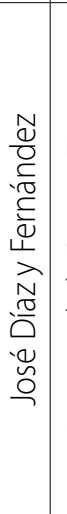 & 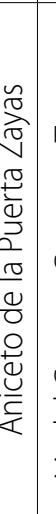 & 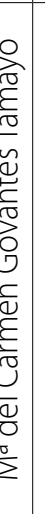 & 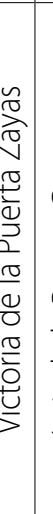 & 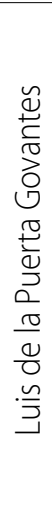 \\
\hline 至 & $\begin{array}{l}0 \\
\stackrel{0}{n} \\
i \\
\frac{1}{\Lambda}\end{array}$ & $\mid \begin{array}{c}\infty \\
0 \\
\stackrel{0}{1} \\
\dot{1} \\
\dot{b}\end{array}$ & 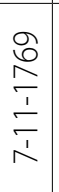 & $\begin{array}{l}\infty \\
\stackrel{0}{2} \\
\frac{1}{\sim} \\
\frac{1}{\sim}\end{array}$ & 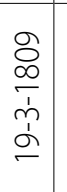 & $\begin{array}{l}\frac{0}{\infty} \\
\infty \\
\grave{b} \\
\infty \\
\infty\end{array}$ & $\begin{array}{l}\frac{N}{\infty} \\
\frac{1}{ \pm} \\
\frac{1}{\sim} \\
\frac{1}{v}\end{array} \mid$ & $\begin{array}{l}n \\
\infty \\
\infty \\
\dot{b} \\
\dot{b} \\
v\end{array}$ & 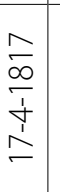 & $\begin{array}{l}\hat{⿱} \\
\infty \\
\frac{1}{0} \\
\stackrel{i}{\sim}\end{array}$ & 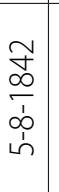 & 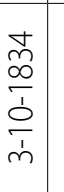 & $\begin{array}{l}8 \\
\infty \\
\infty \\
\dot{m} \\
\frac{1}{m}\end{array}$ & 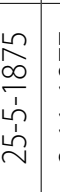 & $\begin{array}{l}\frac{}{\infty} \\
\frac{\infty}{1} \\
\overline{\dot{v}} \\
\dot{v}\end{array}$ & $\begin{array}{l}\infty \\
\infty \\
0 \\
0 \\
\vdots \\
\alpha \\
\sigma\end{array}$ & $\begin{array}{l}\infty \\
\infty \\
\infty \\
\grave{1} \\
\grave{\dot{c}} \\
\dot{v}\end{array}$ & 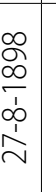 & 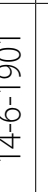 & 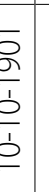 & 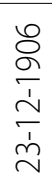 \\
\hline
\end{tabular}




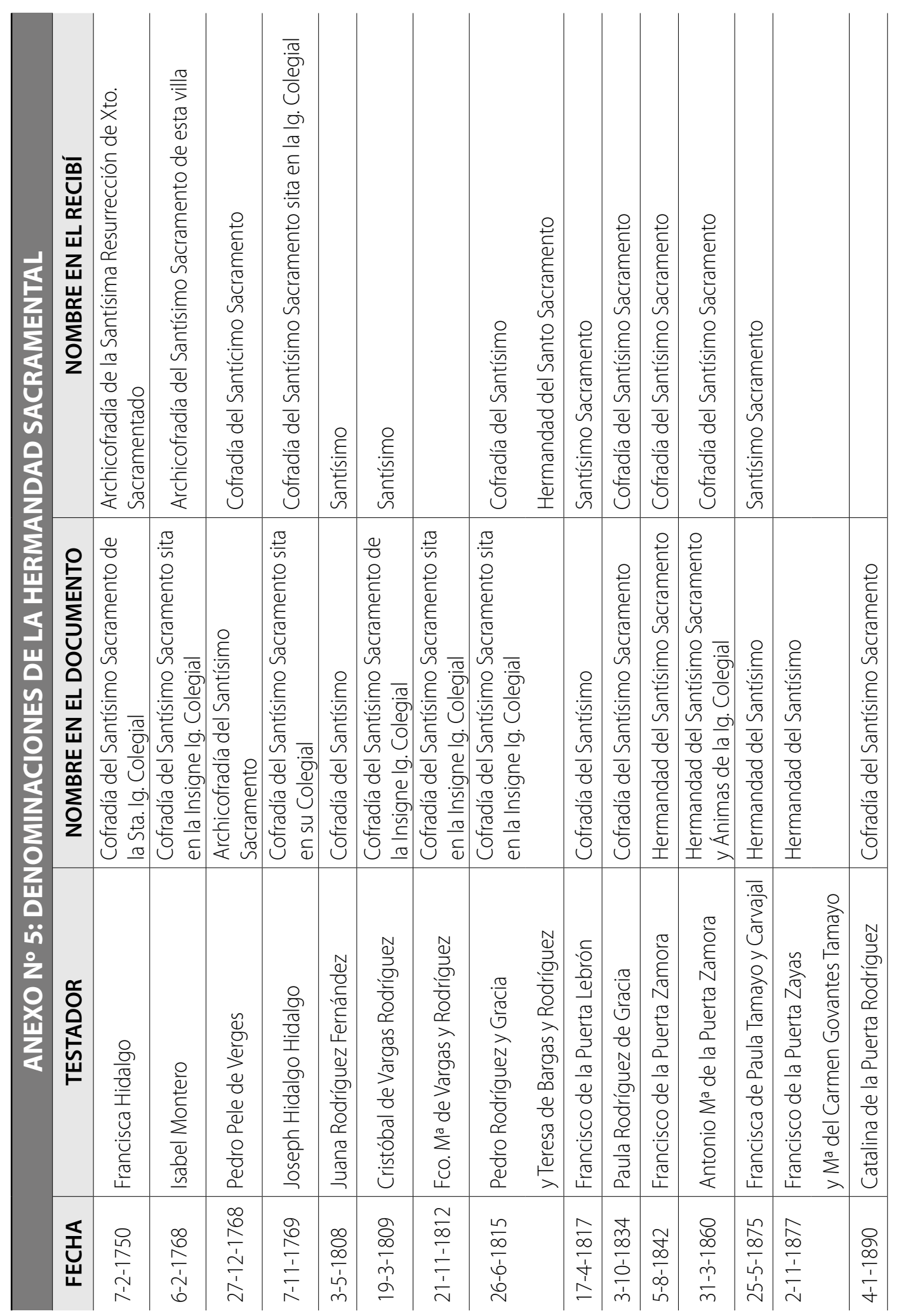




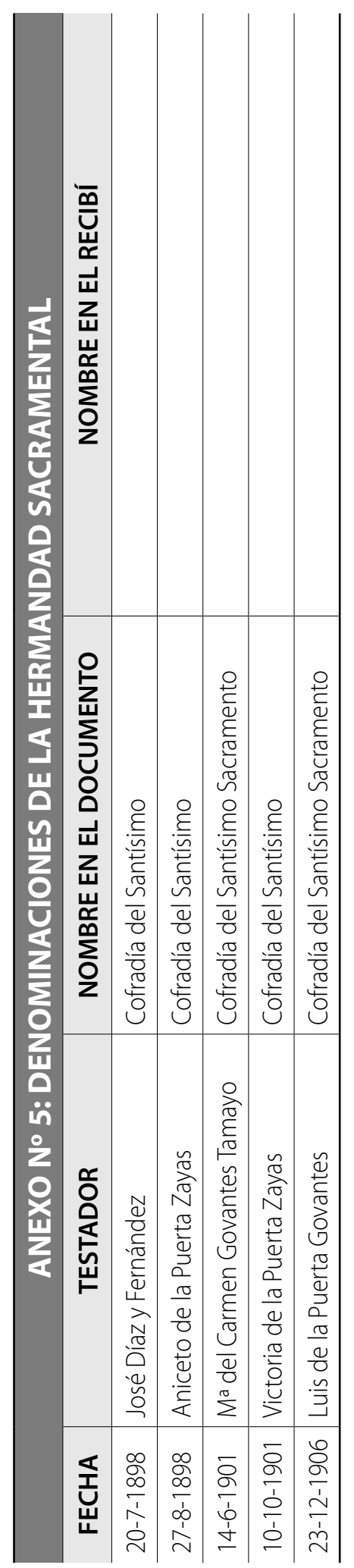




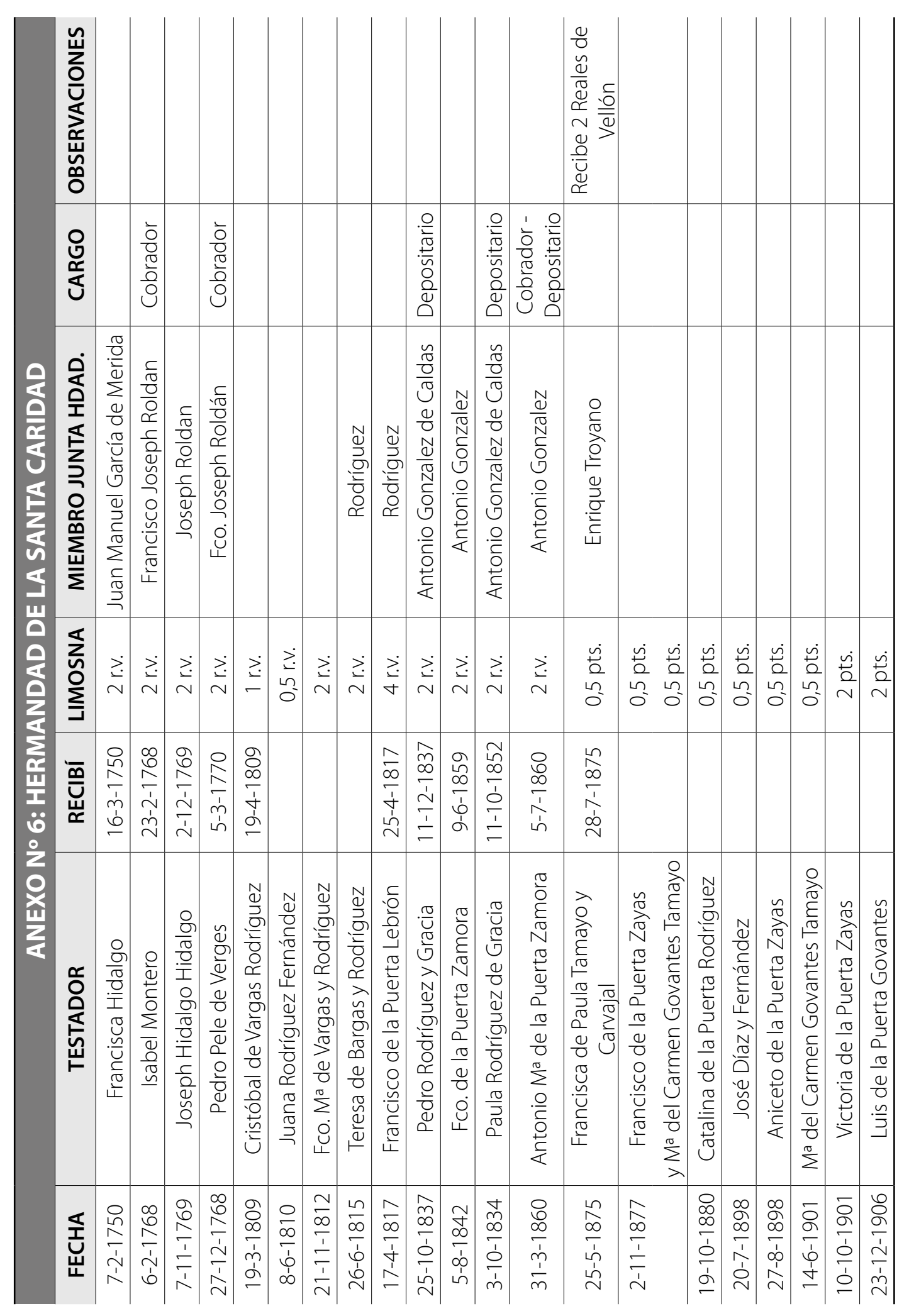




\begin{tabular}{|c|c|c|c|c|c|c|c|c|c|c|c|c|c|}
\hline 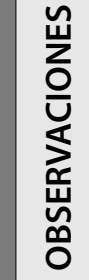 & & & & & & 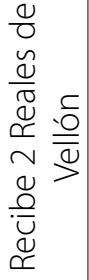 & & & & & & & \\
\hline 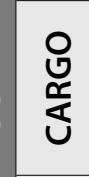 & 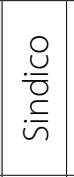 & 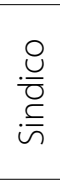 & & & & & & & & & & & \\
\hline 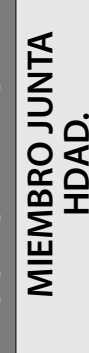 & 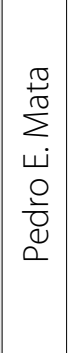 & $\begin{array}{l}\frac{n}{0} \\
\stackrel{0}{0} \\
\sum_{0}^{0} \\
0 \\
0 \\
\frac{0}{0} \\
0 \\
0\end{array}$ & 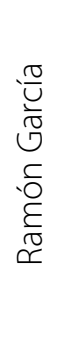 & 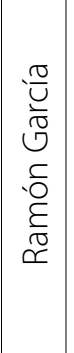 & 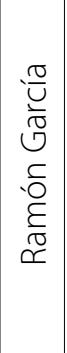 & 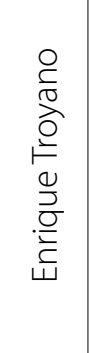 & & & & & & & \\
\hline 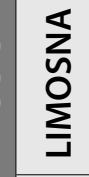 & $\stackrel{\vec{i}}{\sim}$ & $\underset{\forall}{\stackrel{x}{*}}$ & $\begin{array}{l}\overrightarrow{0} \\
\dot{m}\end{array}$ & $\stackrel{\stackrel{x}{v}}{\sim}$ & $\stackrel{\vec{i}}{\sim}$ & \begin{tabular}{l}
$\frac{n}{0}$ \\
\multirow{2}{n}{} \\
0
\end{tabular} & 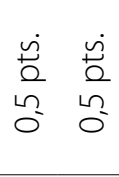 & $\begin{array}{l}\dot{n} \\
\stackrel{\tilde{a}}{2} \\
\tilde{n} \\
0\end{array}$ & 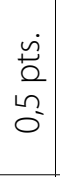 & $\begin{array}{l}\frac{1}{2} \\
\stackrel{2}{2} \\
0 \\
0\end{array}$ & $\begin{array}{l}\text { जी } \\
\frac{\tilde{a}}{\omega} \\
0 \\
0\end{array}$ & 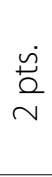 & $\begin{array}{l}\dot{\mathrm{n}} \\
\stackrel{0}{\sim} \\
\sim\end{array}$ \\
\hline 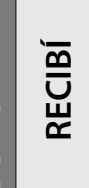 & $\begin{array}{l}\frac{a}{\infty} \\
\bar{b} \\
\dot{b} \\
b\end{array}$ & $\begin{array}{l}\stackrel{N}{\infty} \\
\infty \\
\stackrel{+}{+} \\
\stackrel{\sim}{\sim}\end{array}$ & 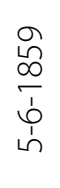 & 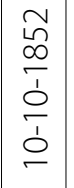 & $\mid \begin{array}{l}8 \\
\infty \\
\infty \\
\frac{1}{1} \\
\dot{m}\end{array}$ & \begin{tabular}{l}
$\stackrel{n}{\nwarrow}$ \\
$\infty$ \\
\multirow{1}{1}{} \\
$\stackrel{\infty}{\infty}$ \\
$\stackrel{\infty}{v}$
\end{tabular} & & & & & & & \\
\hline $\begin{array}{l}\text { 을 } \\
\frac{2}{2} \\
\frac{1}{0}\end{array}$ & 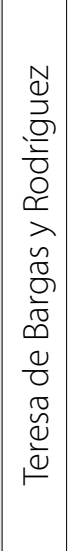 & 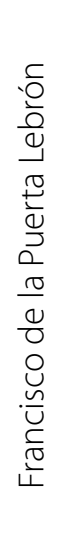 & 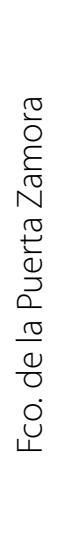 & 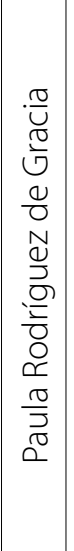 & 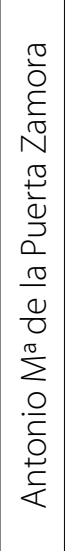 & 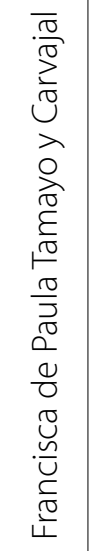 & 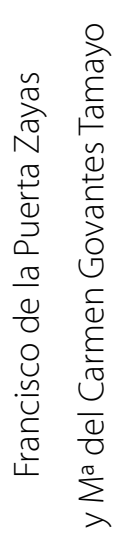 & 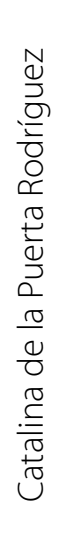 & 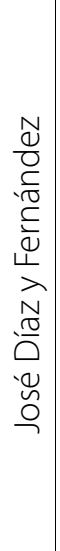 & 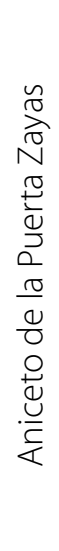 & 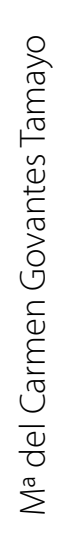 & 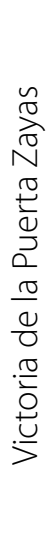 & 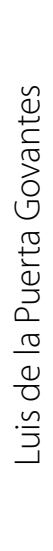 \\
\hline 㜽 & 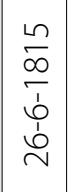 & 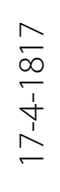 & 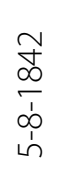 & $\left|\begin{array}{l} \pm \\
m \\
\infty \\
1 \\
0 \\
\dot{1} \\
m\end{array}\right|$ & $\begin{array}{l}8 \\
\& \\
\infty \\
\dot{n} \\
\frac{1}{m} \\
\bar{m}\end{array}$ & 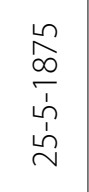 & $\begin{array}{l}\underset{\hat{D}}{\infty} \\
\frac{1}{\perp} \\
\overline{\dot{1}} \\
\dot{\sim}\end{array}$ & $\begin{array}{l}\infty \\
\infty \\
\infty \\
\vdots \\
o \\
\frac{1}{1} \\
\sigma \\
\sigma\end{array}$ & 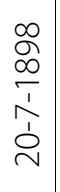 & 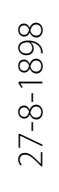 & $\begin{array}{l}\bar{\delta} \\
\frac{\sigma}{1} \\
\dot{1} \\
\dot{1} \\
+\end{array}$ & $\begin{array}{l}\bar{\delta} \\
\frac{8}{b} \\
\frac{1}{1} \\
\frac{1}{0}\end{array}$ & $\begin{array}{l}\stackrel{8}{8} \\
\varnothing \\
\dot{1} \\
\stackrel{1}{\sim} \\
\stackrel{1}{\sim}\end{array}$ \\
\hline
\end{tabular}




\begin{tabular}{|c|c|c|c|c|c|c|c|c|c|c|}
\hline 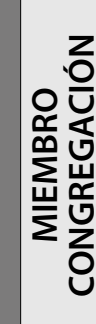 & & & 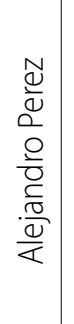 & & 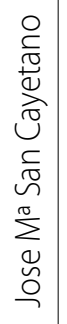 & & 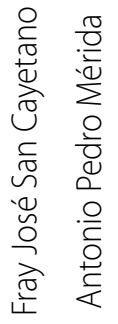 & & & 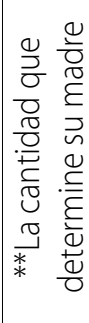 \\
\hline $\begin{array}{l}\sum_{\text {L }} \\
\sum_{j}\end{array}$ & $\stackrel{\gtrless}{\stackrel{i}{\sim}}$ & 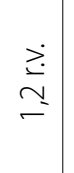 & $\begin{array}{l}\dot{D} \\
\dot{z} \\
\stackrel{b}{m}\end{array}$ & $\stackrel{\stackrel{i}{\sim}}{\sim}$ & $\stackrel{\stackrel{i}{\sim}}{\sim}$ & & 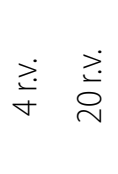 & 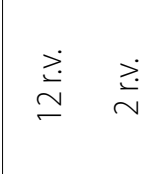 & 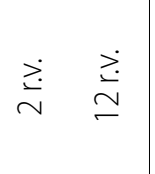 & \\
\hline 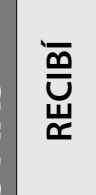 & & & $\begin{array}{l}\frac{0}{\infty} \\
\frac{1}{\alpha} \\
\dot{\alpha} \\
b\end{array}$ & & 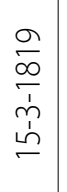 & & 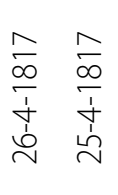 & & & \\
\hline 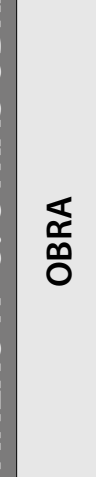 & 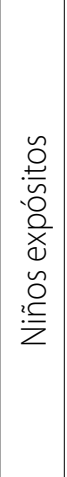 & 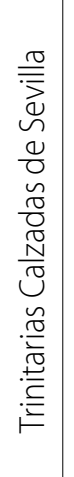 & 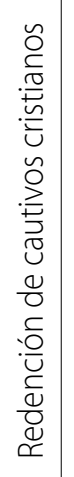 & 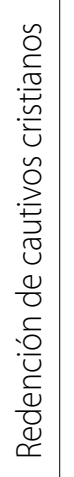 & 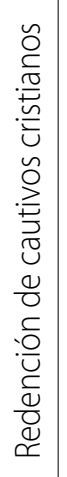 & 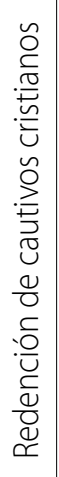 & 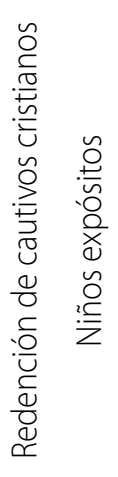 & 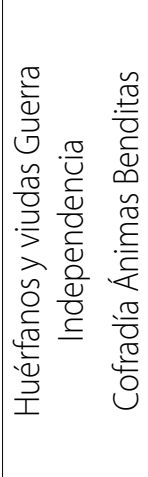 & 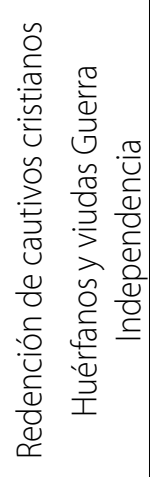 & 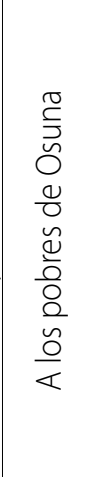 \\
\hline $\begin{array}{l}\text { 은 } \\
\vdots 3 \\
\frac{1}{0}\end{array}$ & $\begin{array}{l}\frac{0}{0} \\
\frac{0}{0} \\
\frac{0}{1} \\
0 \\
\frac{0}{0} \\
\frac{0}{0} \\
\frac{0}{1} \\
\frac{0}{0} \\
\frac{0}{0} \\
\stackrel{0}{0}\end{array}$ & 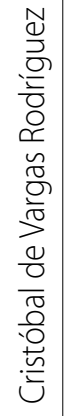 & 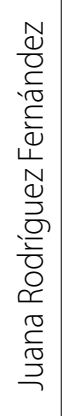 & 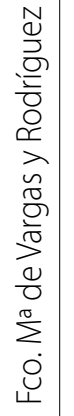 & 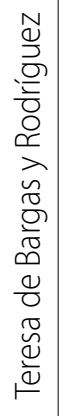 & 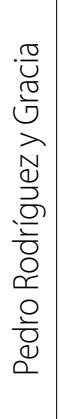 & 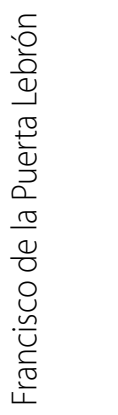 & 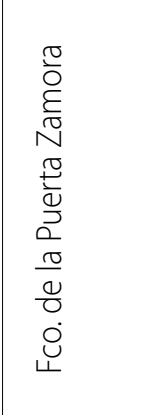 & 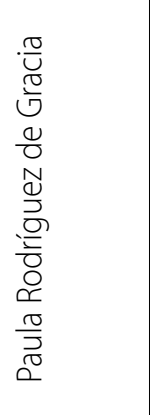 & 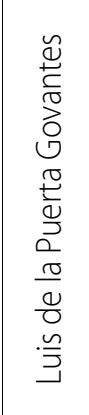 \\
\hline 悫 & $\begin{array}{l}0 \\
\stackrel{0}{2} \\
\frac{1}{ \pm} \\
\frac{1}{1}\end{array}$ & $\begin{array}{l}8 \\
o \\
\infty \\
\dot{n} \\
\hat{\sigma}\end{array}$ & $\begin{array}{l}\frac{0}{\infty} \\
\infty \\
\dot{\phi} \\
\infty\end{array}$ & $\begin{array}{l}\frac{\sim}{\infty} \\
\frac{1}{1} \\
\frac{1}{\sim} \\
\stackrel{1}{v}\end{array}$ & 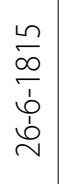 & $\begin{array}{l}n \\
\infty \\
\infty \\
\dot{\phi} \\
\dot{\omega} \\
\stackrel{v}{v}\end{array}$ & $\begin{array}{l}\frac{1}{\infty} \\
\frac{0}{1} \\
\dot{1} \\
\dot{1} \\
-\end{array}$ & 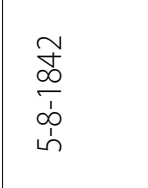 & $\begin{array}{l}\frac{1}{\infty} \\
\frac{\infty}{b} \\
\frac{1}{1} \\
m\end{array}$ & $\begin{array}{l}8 \\
\varnothing \\
\stackrel{1}{1} \\
\stackrel{1}{1} \\
\stackrel{1}{v}\end{array}$ \\
\hline
\end{tabular}




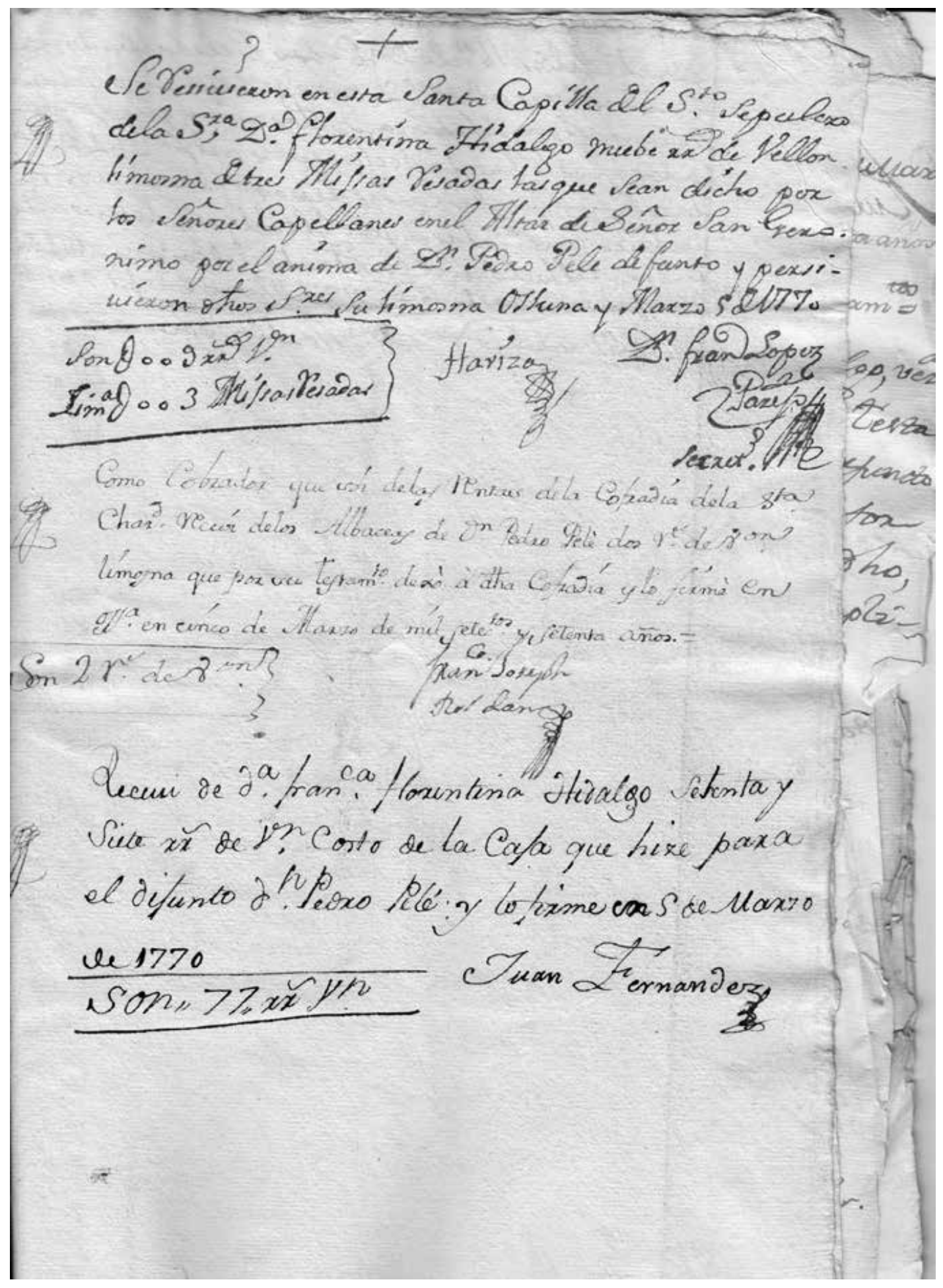

Testamento de Pedro Pele de Verges, año 1768. Justificante de misas, obras pias y caja mortuoria. 


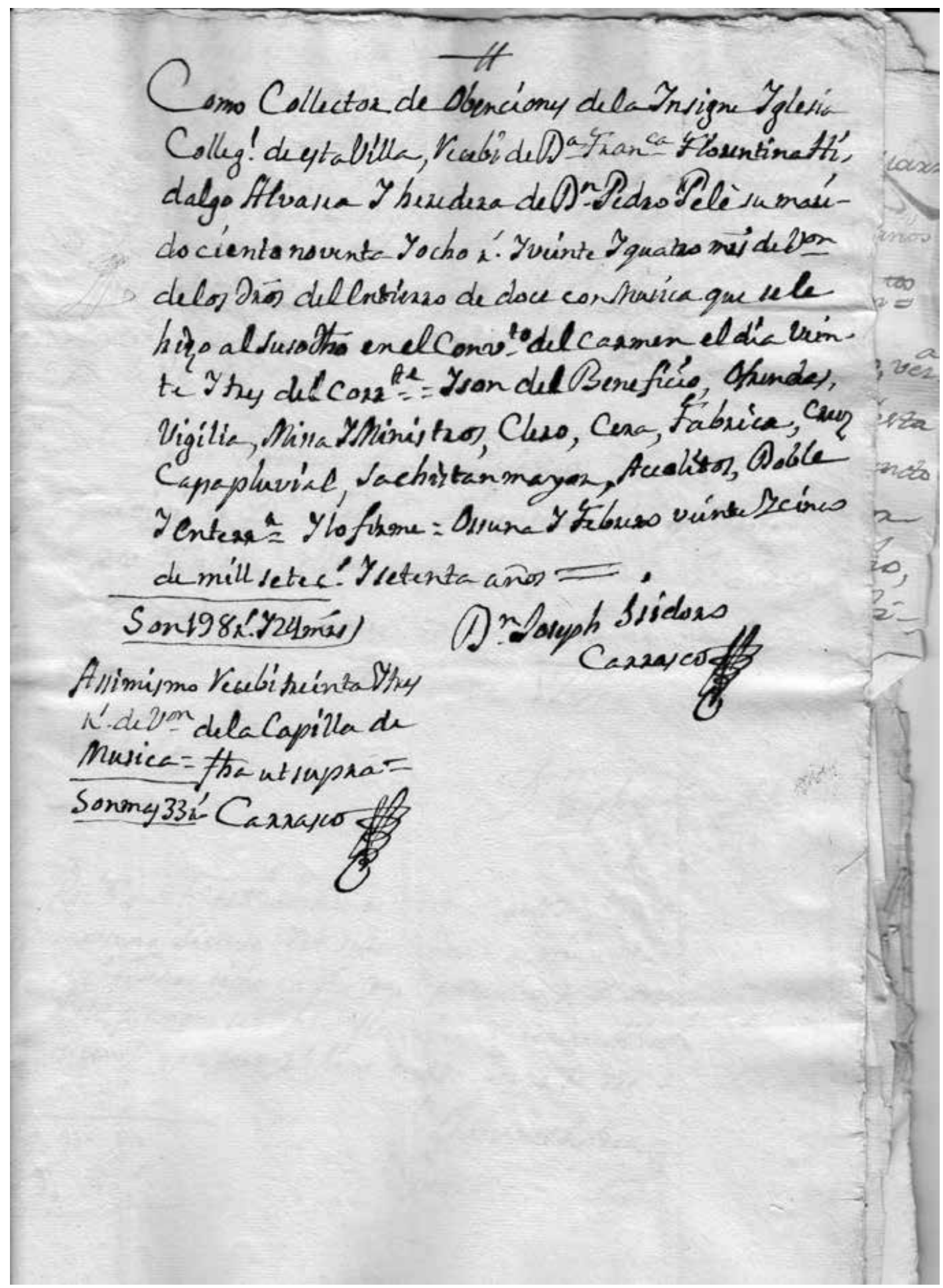

Testamento de Pedro Pele de Verges, año 1768. Justificante del colector de obenciones de la Colegial por los costes del entierro. 


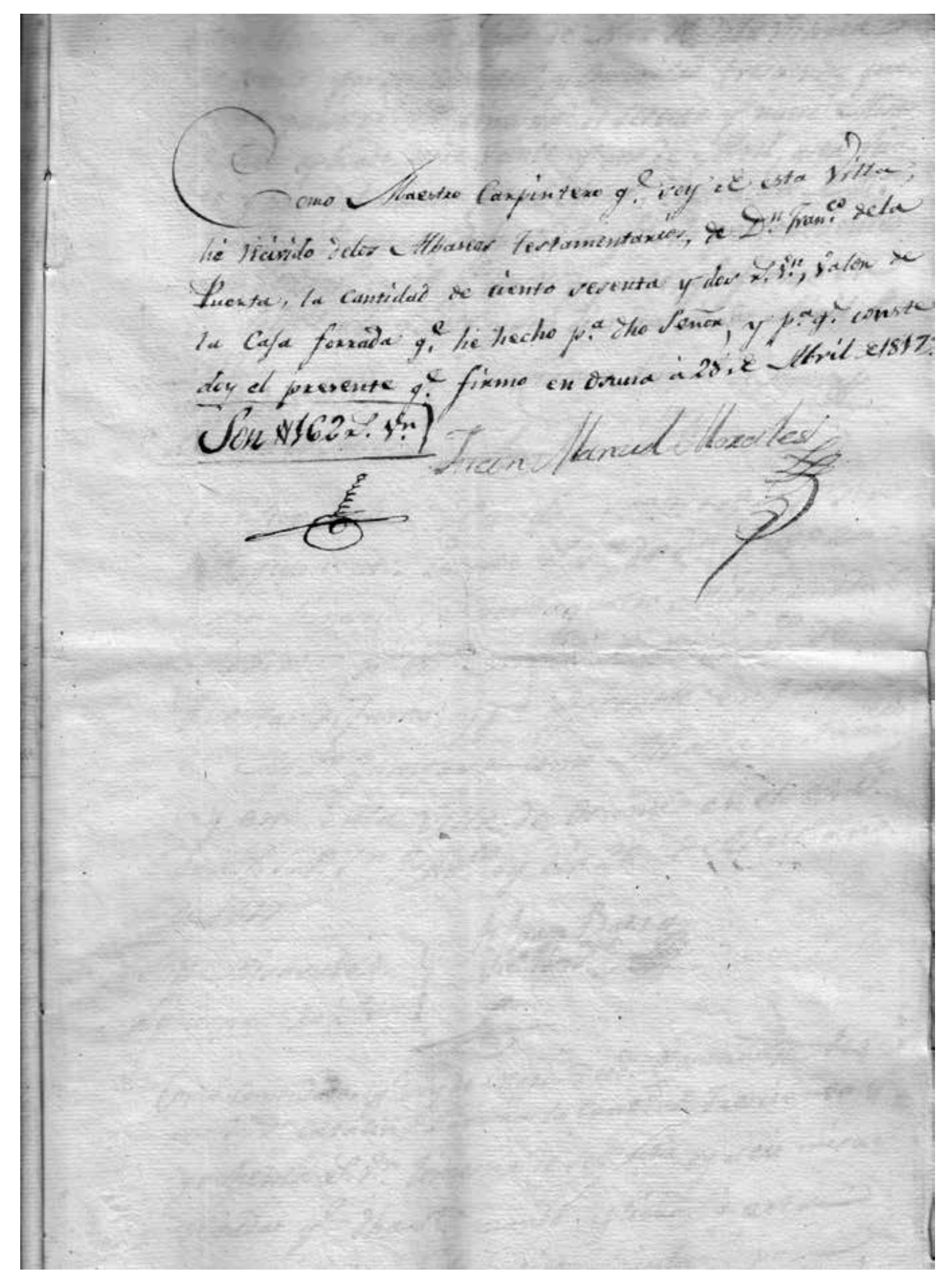

Testamento Francisco de la Puerta Lebrón año 1817. Justificante del coste de la caja forrada. 


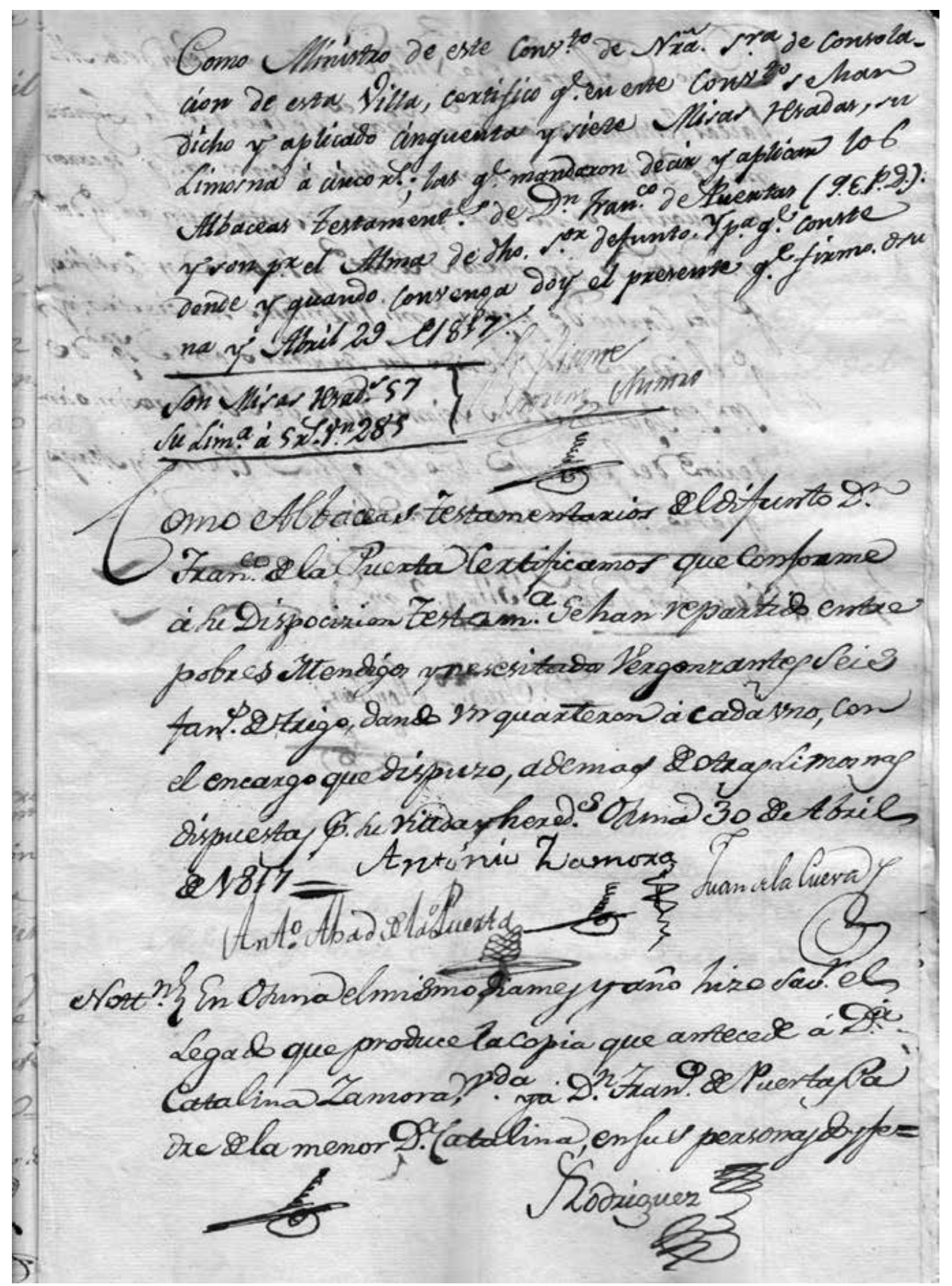

Testamento Francisco de la Puerta Lebrón año 1817. Justificantes de misas y de repartos de pan. 


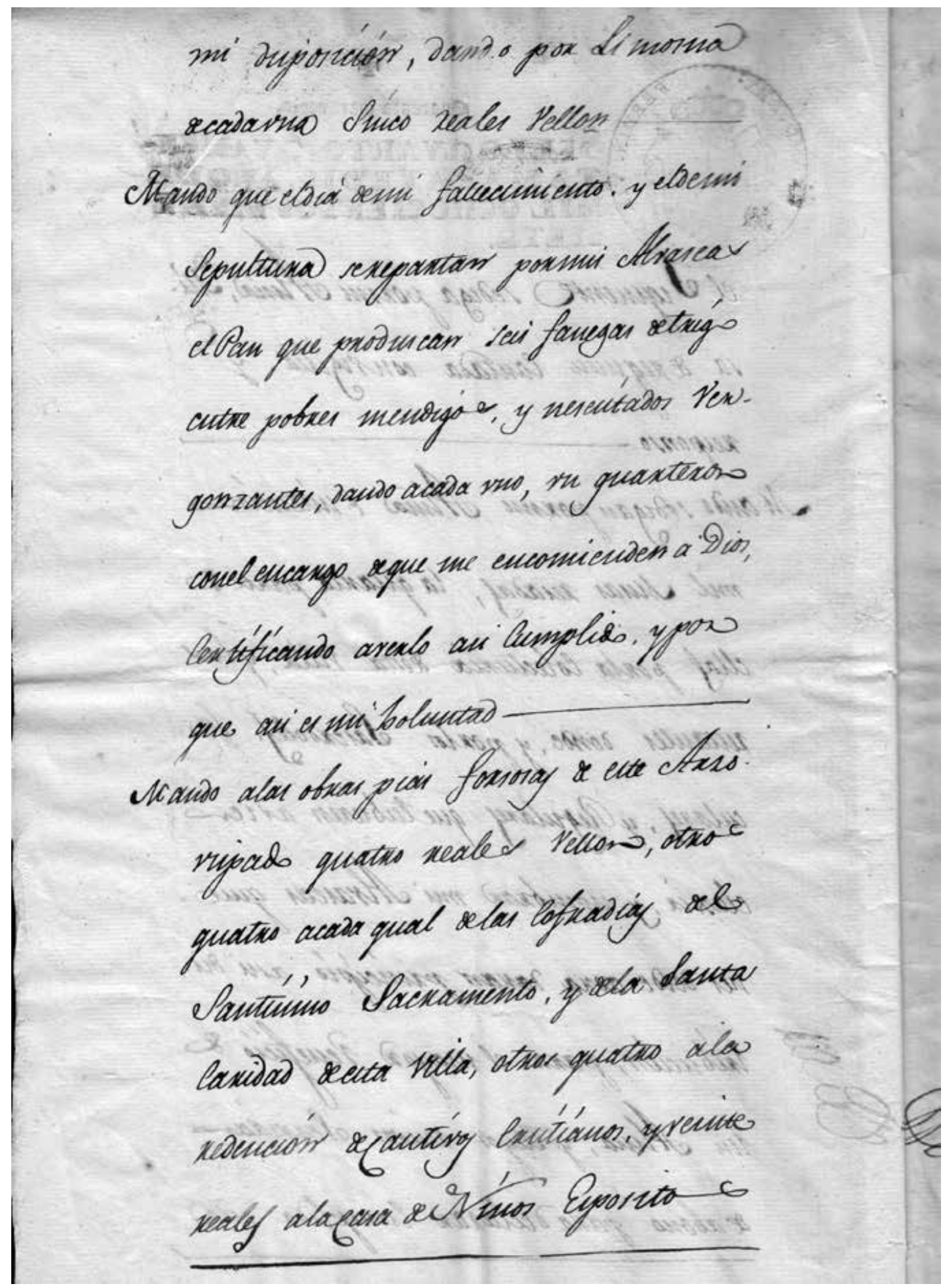

Testamento de Francisco de la Puerta Lebrón año 1817. Petición de entrega de pan a los pobres y las obras pias. 


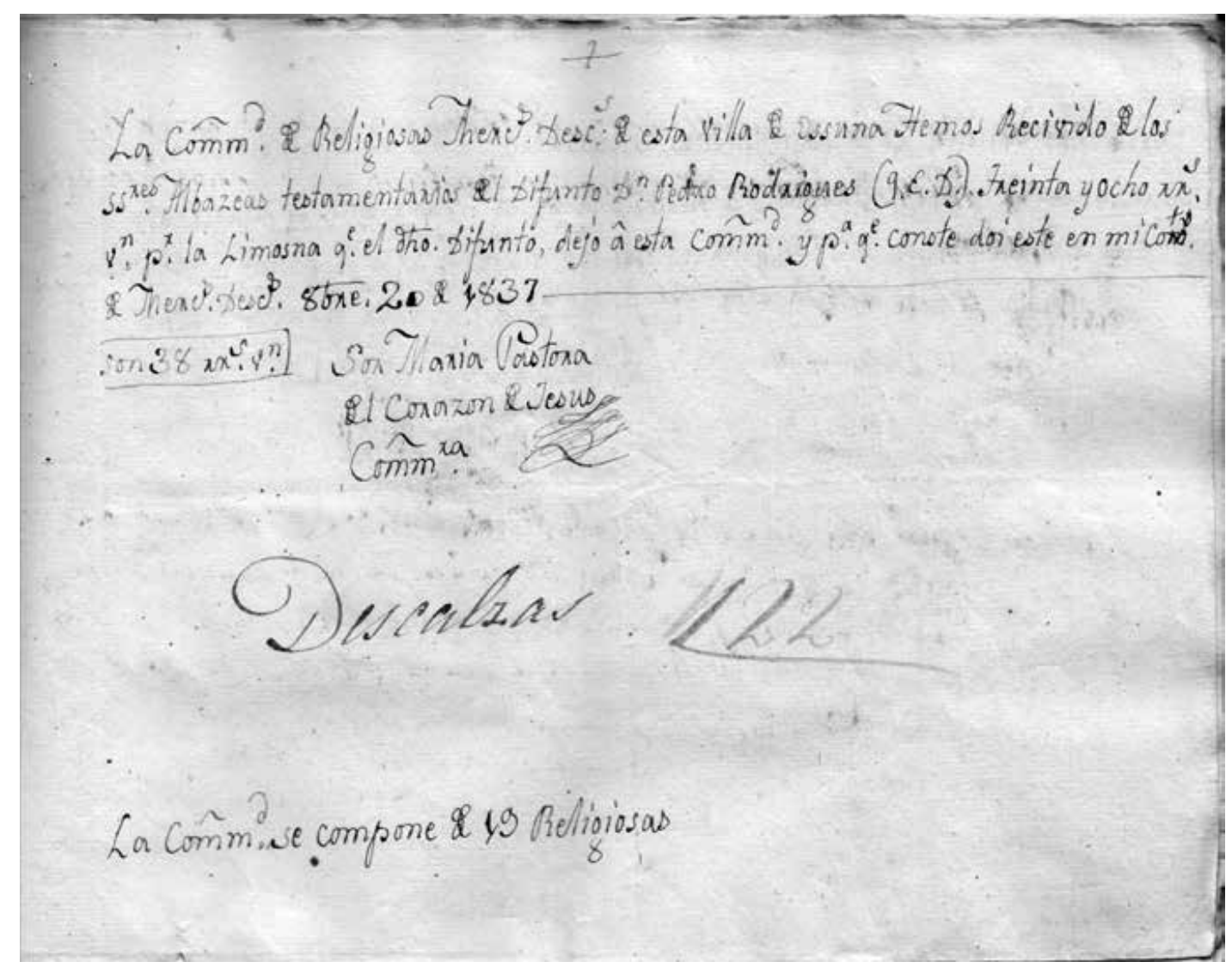

Testamento de Pedro Rodriguez y Gracia, año 1837. Justificante de donativo a las religiosas descalzas. 


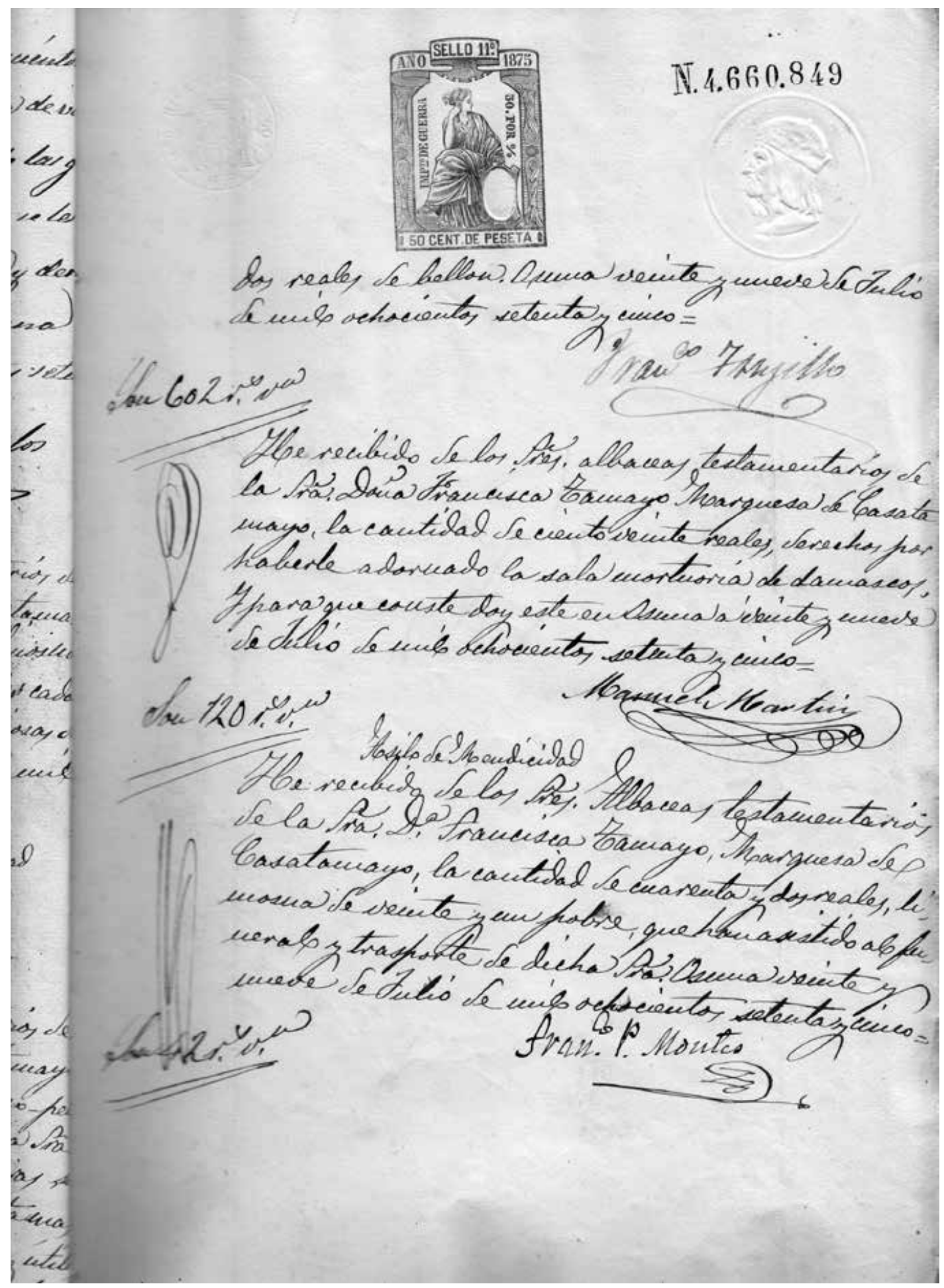

\section{Testamento de Francisca Tamayo y Carvajal, Marquesa de Casa Tamayo,} año 1875. Justificante de donativo a pobres y adorno floral. 